Prepared in cooperation with the

New Hampshire Department of Environmental Services

\title{
Effects of Urbanization on Stream Quality at Selected Sites in the Seacoast Region in New Hampshire, 2001-03
}

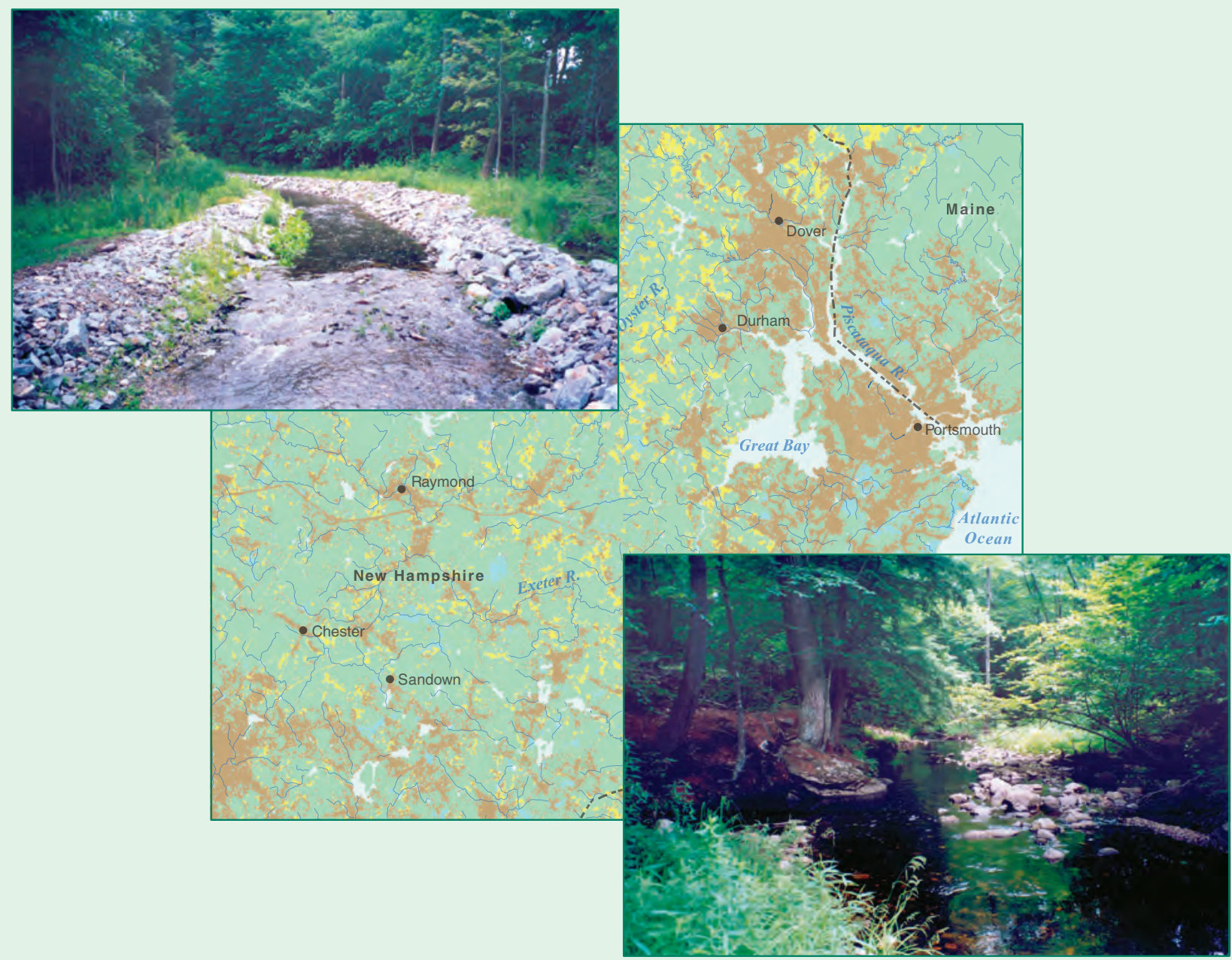

Scientific Investigations Report 2005-5103

U.S. Department of the Interior

U.S. Geological Survey 


\section{Effects of Urbanization on Stream Quality at Selected Sites in the Seacoast Region in New Hampshire, 2001-03}

By Jeffrey R. Deacon, Sally A. Soule, and Thor E. Smith

In cooperation with the New Hampshire Department of Environmental Services

Scientific Investigations Report 2005-5103 


\section{U.S. Department of the Interior \\ Gale A. Norton, Secretary \\ U.S. Geological Survey \\ Charles G. Groat, Director}

U.S. Geological Survey, Reston, Virginia: 2005

For sale by U.S. Geological Survey, Information Services
Box 25286, Denver Federal Center
Denver, CO 80225
For more information about the USGS and its products:
Telephone: 1-888-ASK-USGS
World Wide Web: http://www.usgs.gov/

Any use of trade, product, or firm names in this publication is for descriptive purposes only and does not imply endorsement by the U.S. Government.

Although this report is in the public domain, permission must be secured from the individual copyright owners to reproduce any copyrighted materials contained within this report.

Suggested Citation:

Deacon, J.R., Soule, S.A., and Smith, T.E., 2005, Effects of urbanization on stream quality at selected sites in the Seacoast region in New Hampshire, 2001-03: U.S. Geological Survey Scientific Investigations Report 2005-5103, $18 \mathrm{p}$. 


\section{Contents}

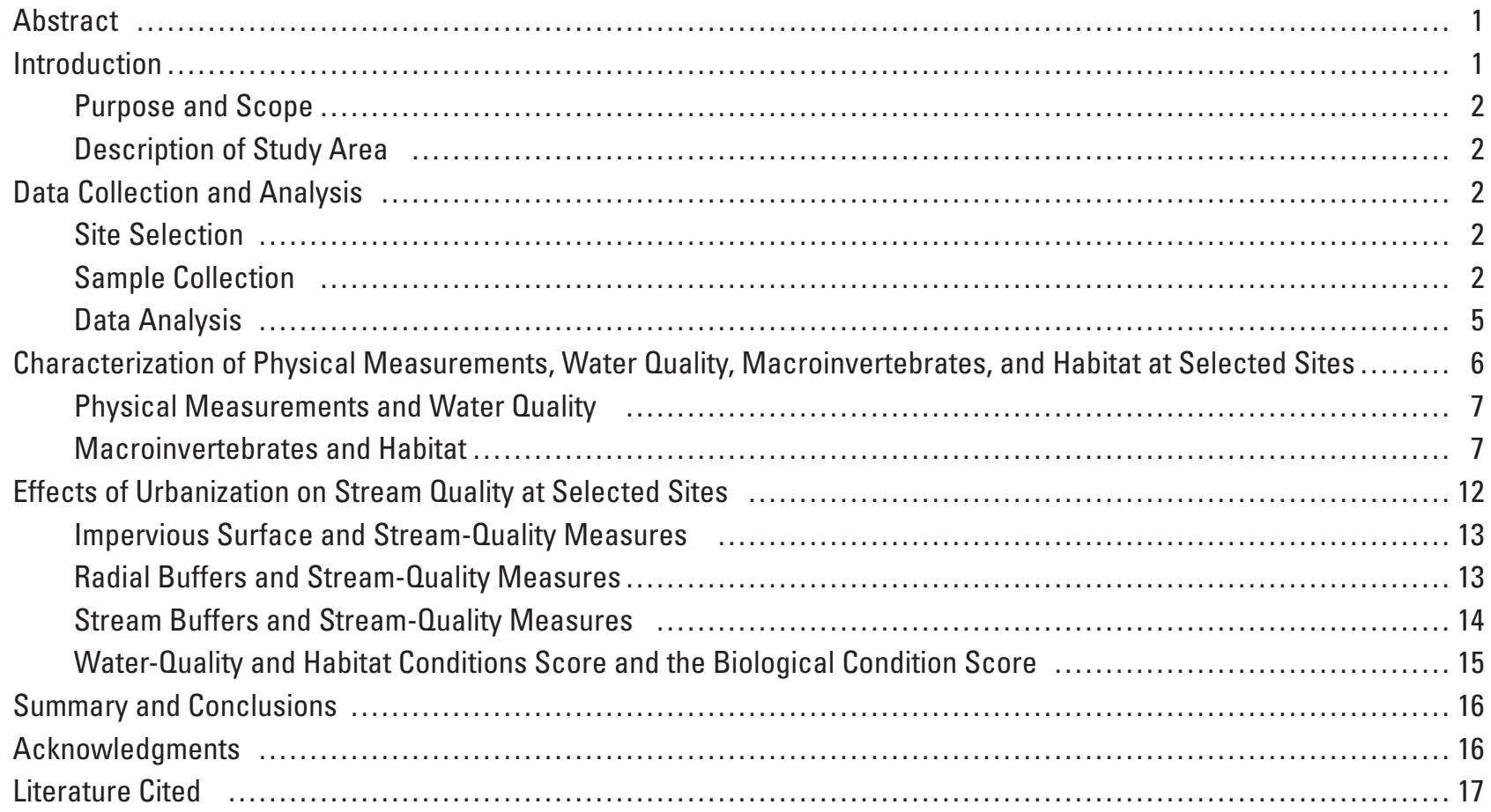

\section{Figures}

1. Map showing sampling sites, site-identification numbers, and land use in the Seacoast region in

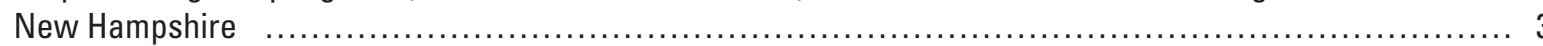

2. Schematic showing (A) 0.5-kilometer, 1-kilometer, and 2-kilometer radial buffers upstream of a sampling site; and (B) a 100-meter stream buffer along the stream corridor, upstream of a sampling site for the Seacoast region in New Hampshire

3. Graph showing mean annual streamflow for historical and study period years from the Oyster River at Durham, N.H.

4. Hydrograph of mean daily streamflow for water years 2001-03 from the Oyster River at Durham, N.H.

5-11. Graphs showing-

5. Mean Escherichia coli concentrations among sampling sites, predominant land use, and percentage

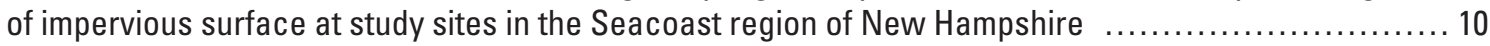

6. Mean nitrite plus nitrate yields among sampling sites, predominant land use, and percentage of impervious surface at study sites in the Seacoast region of New Hampshire

7. Mean value for Ephemeroptera, Plecoptera, and Trichoptera taxa richness among sampling sites, predominant land use, and percentage of impervious surface at study sites in the Seacoast region of New Hampshire

8. Relation between the percent of impervious surface in the watershed and the (A) water-quality and habitat conditions score, (B) biological condition score, and (C) mean Ephemeroptera, Plecoptera, and Trichoptera taxa richness at the study sites in the Seacoast region in New Hampshire... 13 
9. Relation between the percent of urban land in a 1-kilometer radial buffer and the (A) water-quality and habitat conditions score, (B) biological condition score, and (C) mean Ephemeroptera, Plecoptera, and Trichoptera taxa richness at the study sites in the Seacoast region in New Hampshire $\ldots \ldots \ldots \ldots \ldots \ldots . . . .14$

10. Relation between the percent of urban land in a 25 -meter stream buffer and the $(A)$ water-quality and habitat conditions score, (B) biological condition score, and (C) mean Ephemeroptera, Plecoptera, and Trichoptera taxa richness at the study sites in the Seacoast region in New Hampshire 15

11. Relation between the water-quality and habitat conditions score and the biological condition score at the study sites in the Seacoast region in New Hampshire.

\section{Tables}

1. Selected characteristics for the study sites in the Seacoast region in New Hampshire

2. Summary statistics of physical measurements for the study sites in the Seacoast region in New Hampshire

3. Summary statistics of Escherichia coli, nitrite plus nitrate, total phosphorus, and number of pesticide detections from water samples collected at the study sites in the Seacoast region in New Hampshire....

4. Mean values of selected macroinvertebrate metrics for samples collected at each of the study sites in the Seacoast region in New Hampshire

5. Summary of Spearman rank correlations between watershed characteristics and stream-quality variables at the study sites in the Seacoast region in New Hampshire 


\section{Conversion Factors, Abbreviated Water-Quality Units, and Datums}

\begin{tabular}{lcl}
\hline Multiply & \multicolumn{1}{c}{ By } & To obtain \\
\hline & Length & \\
\hline foot $(\mathrm{ft})$ & 0.3048 & meter $(\mathrm{m})$ \\
mile $(\mathrm{mi})$ & 1.609 & kilometer $(\mathrm{km})$ \\
\hline & Area & \\
\hline acre & 0.004047 & square kilometer $\left(\mathrm{km}^{2}\right)$ \\
square foot $\left(\mathrm{ft}^{2}\right)$ & 0.09290 & square meter $\left(\mathrm{m}^{2}\right)$ \\
square mile $\left(\mathrm{mi}^{2}\right)$ & 2.590 & square kilometer $\left(\mathrm{km}^{2}\right)$ \\
\hline & Flow rate & \\
\hline cubic foot per second $\left(\mathrm{ft}^{3} / \mathrm{s}\right)$ & 0.02832 & cubic meter per second $\left(\mathrm{m}^{3} / \mathrm{s}\right)$ \\
\hline
\end{tabular}

Temperature in degrees Celsius $\left({ }^{\circ} \mathrm{C}\right)$ may be converted to degrees Fahrenheit $\left({ }^{\circ} \mathrm{F}\right)$ as follows:

$$
{ }^{\circ} \mathrm{F}=\left(1.8 \times{ }^{\circ} \mathrm{C}\right)+32
$$

Vertical coordinate information is referenced to the North American Vertical Datum of 1988 (NAVD 88).

Horizontal coordinate information is referenced to the North American Datum of 1983 (NAD 83).

Abbreviated water-quality units used in this report:

Chemical concentrations in water are reported in milligrams per liter (mg/L). Milligrams per liter is a unit expressing the concentration of chemical constituents as weight (milligrams) of chemical per unit volume (liter) of water.

Specific conductance is given in microsiemens per centimeter at 25 degrees Celsius ( $\mu \mathrm{S} / \mathrm{cm}$ at $25^{\circ} \mathrm{C}$ ).

Turbidity is reported in Nephelometric Turbidity Units (NTUs).

Concentrations of bacteria in water:

Bacteria concentrations in water are reported in colony counts per $100 \mathrm{~mL}$ (col/100mL). 



\title{
Effects of Urbanization on Stream Quality at Selected Sites in the Seacoast Region in New Hampshire, 2001-03
}

\author{
By Jeffrey R. Deacon, Sally A. Soule, and Thor E. Smith
}

\section{Abstract}

A study of selected water-quality and macroinvertebrate community data was conducted at 10 stream sites in the Seacoast region of New Hampshire to determine if a relation is present between stream quality and the extent of urbanization in a watershed. Watersheds with similar characteristics, but varying in their degree of urban development, were studied. The percent of impervious surface, the percent of urban land use in a watershed, and the percent of urban land use in two types of stream buffers were compared and correlated with stream-quality variables.

Specific conductance, turbidity, nitrite plus nitrate yields, and selected macroinvertebrate community data were significantly correlated with most measures of urbanization used in this study; however, Escherichia coli concentrations and total phosphorus yields were not statistically correlated with most measures of urbanization in this study. The measures of urbanization that had the highest correlations with stream-quality variables were those measures that were associated with the percent of urban land in buffer zones near and upstream of a sampling site. A water-quality and habitat conditions score was negatively correlated with the percent of urban land in a 1-kilometer radial buffer of the sampling site (rho $(r)=-0.86 ; p<0.001)$, the percent of impervious surface $(\mathrm{r}=-0.70 ; \mathrm{p}<0.05)$, and the percent of urban land in the watershed $(r=-0.67 ; p<0.05)$. A biological condition score also was negatively correlated with the percent of urban land in a 1-kilometer radial buffer of the sampling site $(r=-0.95$; $p<0.0001)$, the percent of impervious surface $(r=-0.75$; $\mathrm{p}<0.05)$, and the percent of urban land in the watershed $(r=-0.79 ; p<0.01)$. The percent of urban land in a 25-meter stream buffer along the stream corridor also had negative correlations with a water-quality and habitat conditions score $(\mathrm{r}=-0.80 ; \mathrm{p}<0.01)$ and a biological condition score $(r=-0.86 ; p<0.01)$. Mean Ephemeroptera, Plecoptera, and Trichoptera (EPT) taxa richness showed a response to urbanization in a watershed, indicating that EPT taxa richness may be an appropriate metric to evaluate the effects of urban land use on small streams in this region. Results from this study indicate that the percent of urban land use in buffer zones and the percent of impervious surface in a watershed can be used as indicators of stream quality.

\section{Introduction}

The Seacoast region of New Hampshire, like many other coastal areas in the United States, is experiencing an increase in population and urban development. Urban land use typically expands the area of impermeable surfaces, such as roads, parking lots, sidewalks, and rooftops, which results in increased watershed runoff (Wang and others, 1997). The primary effect of urban development is an increase in impervious surface and the corresponding loss of riparian areas and natural vegetation. Development within a watershed is often quantified in terms of the proportion of the basin area covered by impervious surfaces (Schueler, 1994). Although impervious surfaces do not generate contamination, these surfaces are a major contributing factor leading to physical changes of a watershed that affect stream quality. In other studies, measures of the impervious surface area of about 10 percent have been identified as the level at which stream quality decreases (Klein, 1979; Schueler, 1994; Booth and Reinelt, 1993). In developed watersheds, the chemical composition of runoff often differs from pre-development conditions (Booth and Reinelt, 1993). Increases of up to one order of magnitude may be typical for some contaminant classes, including nutrients and bacteria. A study of coastal New England streams in August 2000 indicated that the greatest change in aquatic communities may occur between low and moderate levels of urban intensity (Coles and others, 2004).

State and local agencies in New Hampshire are concerned about the effects of increasing urban development on water quality and stream biota in the Seacoast region. The combined effects to stream quality of increased development, nonpoint source contamination, and loss of natural vegetation along stream corridors have not been documented in this region. To assess these potential effects, the U.S. Geological Survey (USGS), in cooperation with New Hampshire Department of Environmental Services (NHDES) Coastal Program, designed and operated a surface water-quality monitoring network during 2001-03 to collect water-quality and stream-biota data and to use these data to determine if stream-quality degradation can be observed at a defined level of development and to determine which measures of urbanization may be appropriate indicators of stream quality in a watershed. 


\section{Purpose and Scope}

This report (1) summarizes water-quality and macroinvertebrate data at 10 stream sites, (2) determines the relation between water-quality concentrations and habitat conditions with macroinvertebrate community data and measures of urbanization in a watershed, and (3) determines which measures of urbanization may serve as appropriate indicators of stream quality.

The data discussed were collected from 10 stream sites in subwatersheds of the major coastal tributaries. Five of the 10 stream sites were sampled for 3 years (2001-03). The other five sites were sampled for 2 years (2002-03). Physical measurements (discharge, specific conductance, $\mathrm{pH}$, dissolved oxygen, and turbidity), nutrients, bacteria, macroinvertebrates, qualitative habitat, and pesticide data are presented.

\section{Description of Study Area}

The Seacoast region is a coastal watershed encompassing 1,087 $\mathrm{mi}^{2}$ in southeastern New Hampshire and southern Maine (fig. 1). The region includes diverse ecosystems such as coastal bays, tidal rivers and estuaries, salt marshes, and freshwater rivers, lakes, and ponds. Major rivers include the Oyster, Piscataqua, Lamprey, and Exeter Rivers. The watershed topography ranges from forested, hilly uplands in the north and west, to coastal plains and salt marshes in the east near the Atlantic coast (Stevens and Anderson, 1997). Geology consists of grey marine clays in the flat coastal plain in the lower reaches of the watershed, and in the upper reaches, the geology is composed of a combination of bedrock outcropping at the surface, mixed glacial materials (sand, gravel, silts, and clays), and hardened, dried soils (Short, 1992). Air temperatures range from $-29^{\circ}$ to $35^{\circ} \mathrm{C}$, and precipitation averages about 44 inches per year, with most falling during the winter season. Slightly less than half of the annual precipitation falling on the coastal watershed is lost through evaporation, with the remainder divided between surface runoff and groundwater discharge (David Brown, University of New Hampshire, written commun., 2005).

Many areas in the Seacoast region are experiencing increased population growth and development. Coincident with population increase is the increasing development of new impervious surfaces from roads, parking lots, commercial buildings, homes, and other developments which can increase runoff to streams. Between 1990 and 2000, impervious surfaces covering 11,154 acres were created in the coastal watershed (New Hampshire Estuaries Project, 2003). Land use in the watershed consists of highly urbanized regions in the easternmost section of the watershed along the coast to rural and residential regions (urban) in the northern and western areas (fig. 1). Forty-three municipalities are located in the New Hampshire part of the coastal watershed including cities such as Portsmouth, Dover, Durham, Exeter, and Hampton and rural communities such as Chester, Sandown, and Raymond (fig. 1).

\section{Data Collection and Analysis}

The sampling program for this study was designed to compare selected stream-quality measures to measures of urbanization in a watershed. This study collected data on physical measurements, bacteria, nitrogen, and phosphorus concentrations and macroinvertebrate communities and correlated these data to the extent of urbanization in a watershed.

\section{Site Selection}

Approximately 40 stream sites were initially categorized by stream size, percent of land use types, and population density in the watershed. The selection of 10 sites utilized a process which included topographic map inspection and field reconnaissance. Generally, sites were selected to determine if streams draining watersheds with similar physical characteristics (basin size, geology, geographical location, and instream features), but varied in degrees of urban land in the watershed, would indicate decreasing quality as the amount and extent of urbanization increased. Five sites were selected in populated areas where the predominant land use near and upstream of the sampling site is urban (table 1, fig. 1). The additional five sites were selected in rural areas where the predominant land use near and upstream of the sampling site is forest (table 1, fig. 1). A geographic information system (GIS) was then used to determine other watershed characteristics (the percent impervious surface and the percent of urban land use within stream buffers) of these sites. The sites in this study ranged from 1.8 to 38 percent impervious surface in the watershed. The five sites having urban as the predominant land use near and upstream of the sampling site had between 15 and 38 percent impervious surface in the watershed. The five sites having forest as the predominant land use near and upstream of the sampling site had between 1.8 and 6.5 percent impervious surface in the watershed.

\section{Sample Collection}

Water-column samples were collected using standard surface-water protocols (Wilde and Radtke, 1998a and b). Physical measurements consisted of streamflow, specific conductance, $\mathrm{pH}$, dissolved oxygen, and turbidity. Instantaneous streamflow (discharge) was measured using streamflowgaging methods described by Rantz and others (1982). Water samples were analyzed for Escherichia coli (E. coli), nitrite plus nitrate, and total phosphorus concentrations. Water samples were analyzed once for a suite of 61 pesticide compounds, predominantly consisting of organochlorine, polycyclic aromatic hydrocarbons (PAHs), and thalates, during the study to determine their occurrence and distribution.

E. coli has been identified by the U.S. Environmental Protection Agency (USEPA) as the preferred and most useful fecal indicator of the freshwater quality of recreational waters 


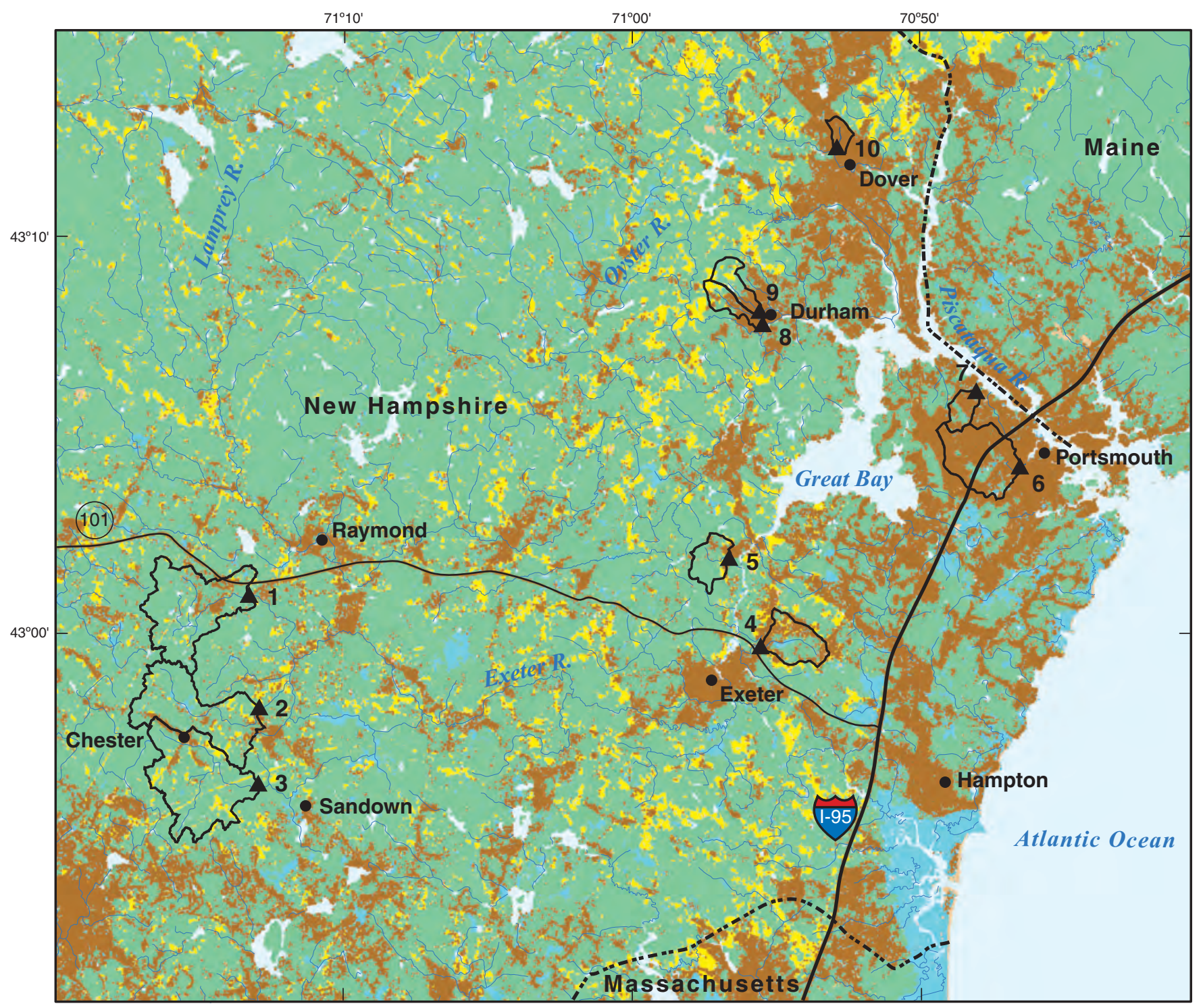

Land Use data from U.S. Geological Survey National Land Cover Dataset, 1992

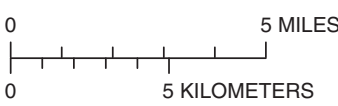

\section{EXPLANATION}
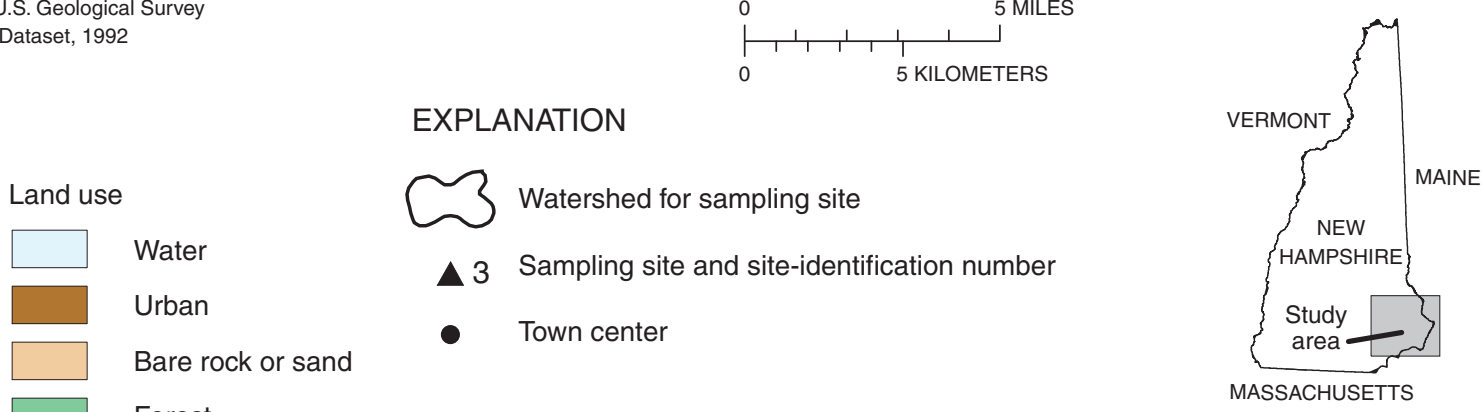

Forest

Agriculture

Wetland

Figure 1. Sampling sites, site-identification numbers, and land use in the Seacoast region in New Hampshire. (Site identification numbers and names are shown in table 1.) 
Table 1. Selected characteristics for the study sites in the Seacoast region in New Hampshire.

[USGS, U.S. Geological Survey; Latitude and longitude are given in degrees ${ }^{\circ}$, minutes', and seconds"; mi², square miles; $\mathrm{km} / \mathrm{km}^{2}$, kilometers per square kilometer]

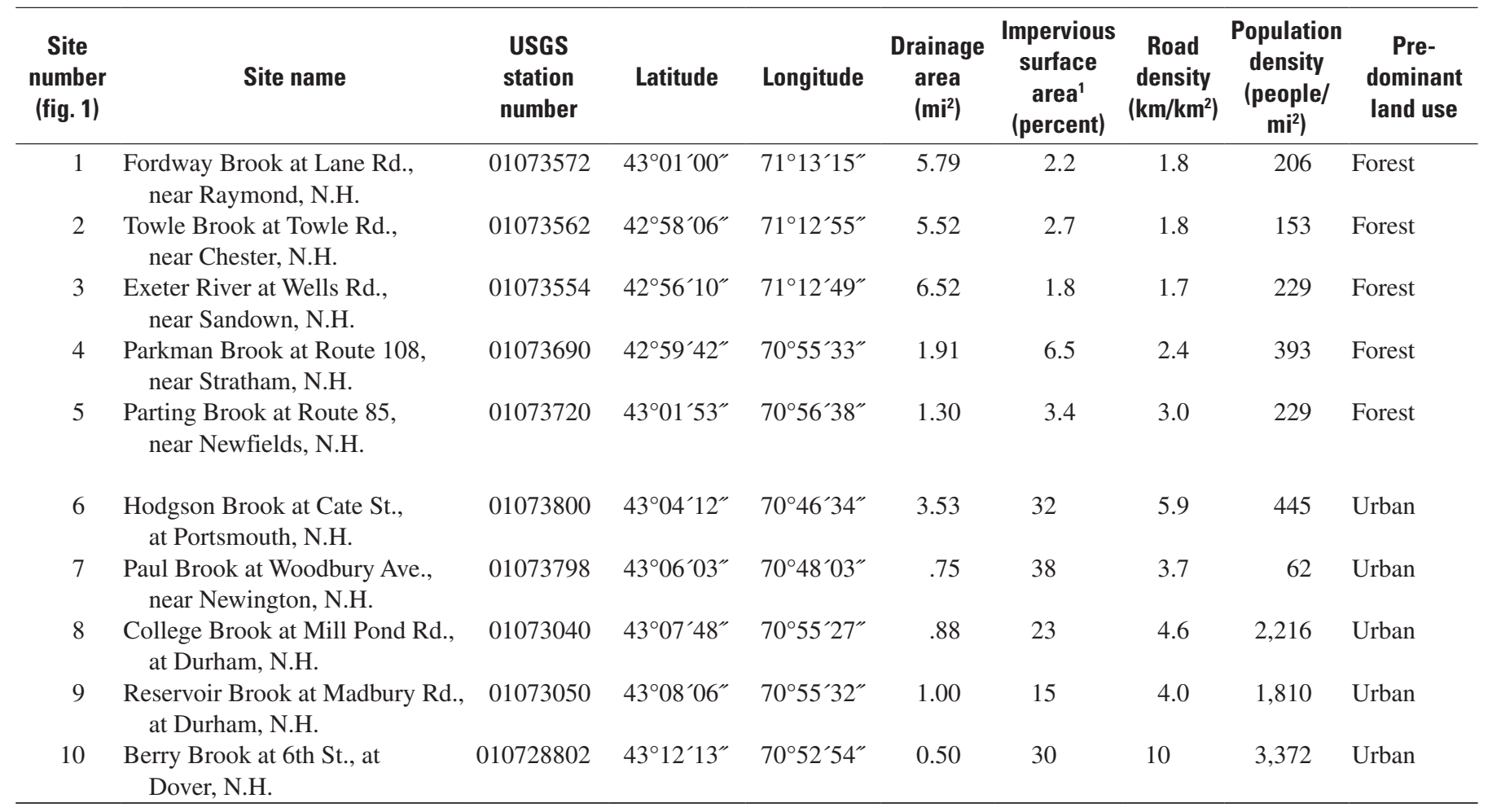

${ }^{1}$ Rubin and Justice, 2001.

for body contact (Dufour, 1984). Algae and aquatic vegetation depend on nitrogen and phosphorus compounds for nutrient supply (Hem, 1992). However, excessive concentrations of nutrients may lead to an overabundance of aquatic plants resulting in decreased dissolved oxygen levels, loss of available habitat for macroinvertebrates, and decreased aesthetics.

Samples were collected at sites 1 through 5 in 2001-03 and sites 6 through 10 in 2002-03 (table 1). Water-column samples were collected monthly between June and November in 2001, and between March and October in 2002 and 2003. The monthly sampling represents various weather conditions that may effect water-sample concentrations during the study as a result of increased runoff during rain or snowmelt events. All water-column samples were analyzed at the NHDES Laboratory in Concord, N.H. Results of the physical and the waterquality data for all sampling sites are in the USGS National Water Information System (NWIS).

Quality-control procedures included analysis of field blank and replicate samples. Field blanks provide information on bias or the potential for contamination of analytical results by sample collection, processing, and analysis. Analytical results from the field blank samples showed that concentrations for all constituents discussed in this report were less than the laboratory reporting level. Replicate samples provide information on the variability of analytical results caused by sample collection, processing, and analysis. Differences in concentrations between environmental and replicate samples for $E$. coli colonies per $100 \mathrm{~mL}$ were generally less than 20 percent. Differences in concentrations in environmental and replicate samples for nitrite plus nitrate and total phosphorus were generally less than 0.01 and $0.005 \mathrm{mg} / \mathrm{L}$, respectively. It was concluded that sample processing and analysis did not introduce enough variation in the environmental data to affect interpretation of results.

A number of studies have shown that macroinvertebrate community data can be used as indicators of stream quality (Benke and others, 1981; Shaver and others, 1994; Schueler and Galli, 1992; Pederson and Perkins, 1986; Garie and McIntosh, 1986). These data can be useful in evaluating stream quality because macroinvertebrate habitat preference and their low motility cause them to be affected directly by water quality and habitat conditions. Macroinvertebrate samples were collected once each year in July during the low-flow summer period using a Surber square-foot sampler. Samples were collected from five representative areas of riffle habitat containing primarily rock substrates (Cuffney and others, 1993). The five subsamples were composited into one sample for each site. The samples were preserved with 70-percent ethanol. Macroinvertebrate samples were analyzed for species composition and abundance and were identified to genus/species level and enumerated at EcoAnalysts, Moscow, Idaho. 
One important aspect of relating biological communities to water quality is the assessment of available habitat for aquatic organisms. Habitat-assessment data were collected according to the USEPA's Rapid Bioassessment Protocols (RBPs) (Barbour and others, 1999). This process involves rating 10 habitat parameters as optimal, suboptimal, marginal, or poor. RBPs provide a qualitative assessment of stream habitat features such as substrate and instream cover, riffle/ run/pool ratio, channel morphology, bank features, and riparian vegetation. A total score is calculated based on individual scores of the dominant habitat features. Each habitat variable was categorized, and a total score of the variables provided a qualitative assessment of each site.

\section{Data Analysis}

For purposes of this study, the percent of impervious surface, urban land use in the entire watershed and urban land use within two types of stream buffers were selected for use in correlating the extent of watershed urbanization to stream quality. Impervious surface area was calculated using 30-m Landstat 5 thematic mapper satellite image data with subpixel classification (Rubin and Justice, 2001). The national land cover data (NLCD) with 30-m pixels was used to calculate urban land-use statistics in each watershed (U.S. Geological Survey, 1992). Stream buffers were calculated using the 1:24,000 digital line graph data (U.S. Geological Survey, 1995). Two types of stream-buffer variables, each with various distances in relation to the sampling site, were used for data analysis. The first stream-buffer variable and the various distances of the buffer that were selected for data analysis was the percent of urban land within a $0.5-\mathrm{km}, 1-\mathrm{km}$, and $2-\mathrm{km}$ radius of the sampling site, termed radial buffer in this report (fig. 2). The second stream-buffer variable and the various distances of the buffer that were selected for data analysis was the percent of urban land within a 25-m, 100-m, and 250-m corridor upstream of the sampling site, termed stream buffer in this report (fig. 2).

A Spearman rank correlation test (Helsel and Hirsch, 1992) was used to determine the strength of association between two variables, such as the percent of impervious surface and a biological condition score, and to identify stream-quality measures that might be useful in monitoring urban effects. Correlations were considered significant if the probability was less than 5 percent $(\mathrm{p}<0.05)$.

To compare water-quality and habitat conditions to macroinvertebrate data and to the measures of urbanization at each site, a water-quality and habitat conditions score (WQHS) was developed, on the basis of data from this study, that includes five water-quality parameters and one habitat parameter. The six parameters, which are assumed to be independent of each other, were $E$. coli concentrations, nitrite plus nitrate yields, specific conductance, turbidity, the number of pesticide detections, and a qualitative habitat score. Median values were used in the analysis for four of the parameters $(E$. coli concentrations, nitrite plus nitrate yields, specific conductance, turbidity). Median values are used to represent typical water-quality conditions at each site to eliminate the effect of outlying concentrations from varying stream conditions during a sampling event. Single values were used in the analysis for two of the parameters (the number of pesticide detections and a qualitative habitat score). Sampling for pesticide occurrence and assessing the habitat was conducted once at each stream site during stable streamflow and weather conditions.

Nitrite plus nitrate yields were calculated based on nitrite plus nitrate concentrations, stream discharge, and basin area and are expressed in kilograms per day per square mile $\left(\mathrm{kg} / \mathrm{day} / \mathrm{mi}^{2}\right)$. Each site was ranked in the same way with a score from 1 to 10 that represented the quality of that measurement at that site relative to all the other sites. The five waterquality parameters were ranked high to low corresponding to the lowest to highest concentrations or values of each of the five parameters at all sites. The habitat parameter was ranked high to low corresponding to the highest to lowest values at all sites. Individual site WQHS rankings for each of the six parameters were summed to arrive at a final WQHS for a particular site. These scores represent the overall water-quality and habitat conditions and were used to examine differences among sites in this study.

To compare macroinvertebrate data to the WQHS and to measures of urbanization at each site, single- and multi-metric approaches were used. Single metrics, such as richness and composition measures, were used in evaluating the macroinvertebrate community. Total taxa richness and Ephemeroptera, Plecoptera, and Trichoptera (EPT) richness, or the number of distinct taxa, represents the diversity within a sample and measures the overall variety of the macroinvertebrate assemblage (Barbour and others, 1999). Composition measures, such as the percent dominant taxa is a simple measure of redundancy. A high level of redundancy is equated with the dominance of contaminant tolerant organisms and a decreased diversity (Barbour and others, 1999). The mean value from the macroinvertebrate samples collected during the study was used in the analysis of the macroinvertebrate data.

The overall biological condition of the macroinvertebrate community was expressed in terms of a multi-metric approach based on the macroinvertebrate community structure, group tolerances, and functional feeding groups at that site, and was determined for all sites using a biological condition score (BCS) (Rosenberg and Resh, 1993). The BCS is an index that is determined by ranking biotic metrics that are commonly used in bioassessment studies. The metrics used to determine a BCS at sites in this study are taxa richness, the Hilsenhoff biotic index, the ratio of scraper to collector-filterer abundances, the ratio of EPT to chironomid abundances, the percent of dominant taxon, number of EPT taxa, and the ratio of shredders to total abundance of all macroinvertebrates at a site (Rosenberg and Resh, 1993). Except for the dominant taxon and the Hilsenhoff Index, all metrics were ranked from high to low, corresponding to the highest to lowest numbers or percentages of each of the metrics at all sites. In other words, 


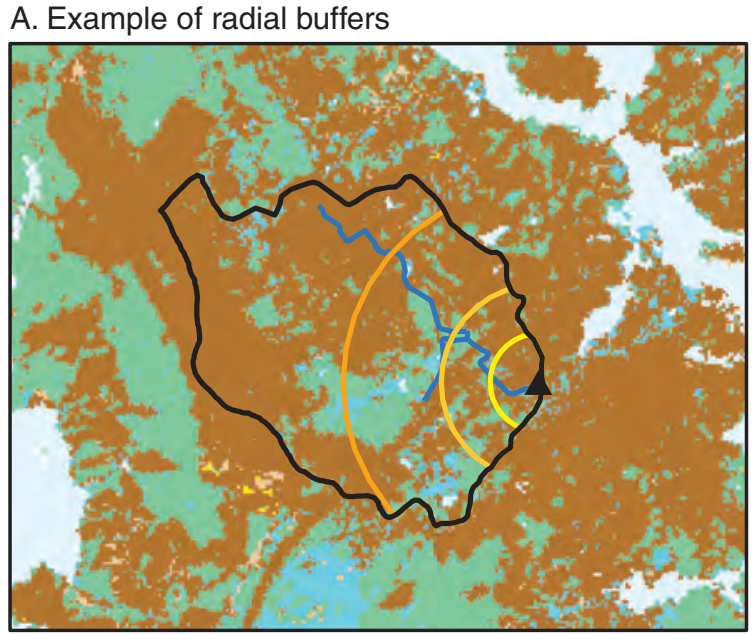

Hodgson Brook near Portsmouth, $\mathrm{NH}$, sampling site 6

\section{B. Example of stream buffer}

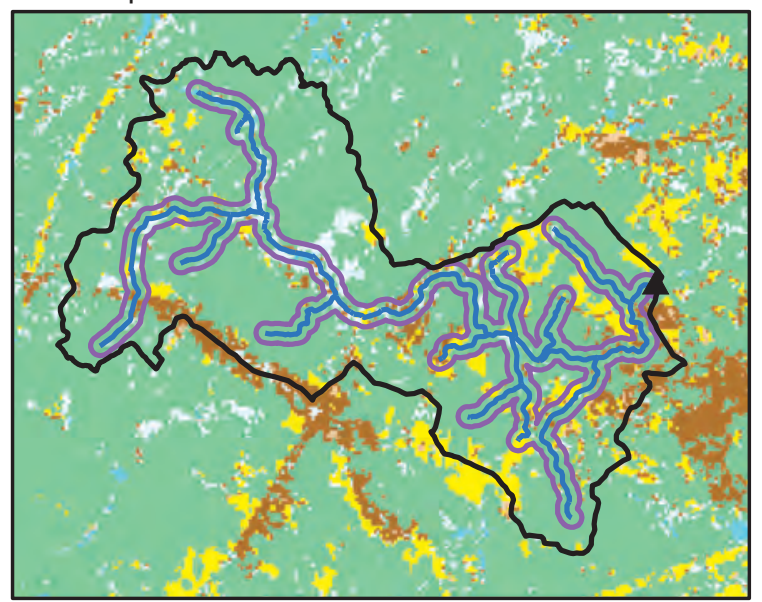

Towle Brook at Towle Road near Chester, NH, sampling site 2
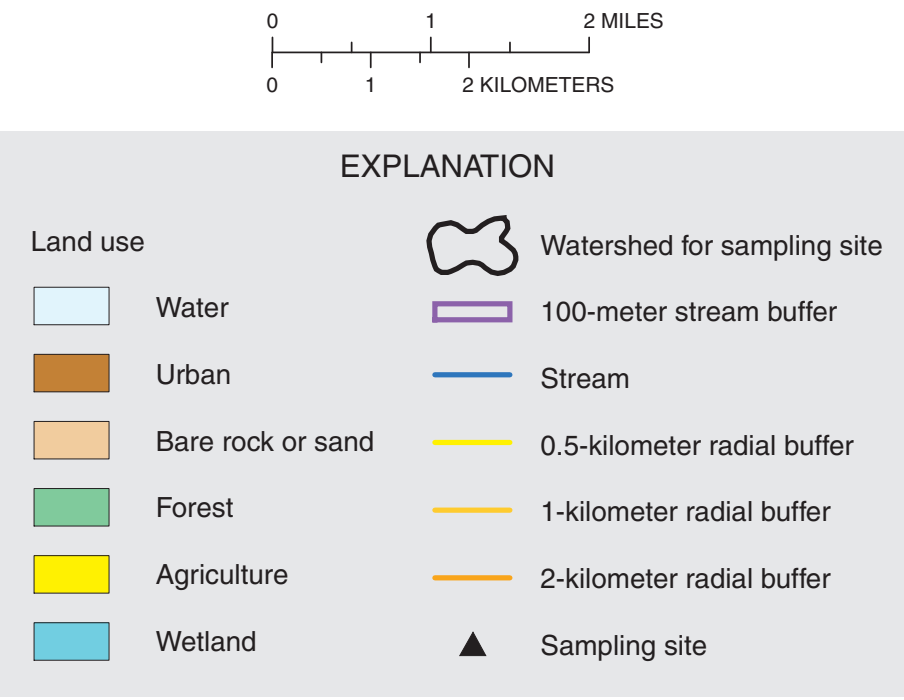

Figure 2. Schematic showing (A) 0.5-kilometer, 1-kilometer, and 2-kilometer radial buffers upstream of a sampling site; and (B) a 100-meter stream buffer along the stream corridor, upstream of a sampling site for the Seacoast region in New Hampshire. (Also calculated, but not shown are 25-meter and 250-meter stream buffers.).

the numbers and percentages of these metrics decrease in response to increasing disturbance. According to Barbour and others (1999), percent of dominant taxon and the values of the Hilsenhoff Index increase in response to increasing disturbance; therefore, these two metrics were ranked from high to low based on lowest to highest numbers or percentages.

The WQHS and the BCS were used to examine differences in these scores among study sites, the relation between water-quality and habitat conditions and macroinvertebrate communities to measures of urbanization in a watershed, and the relation between water-quality and habitat conditions and macroinvertebrate communities. All statistical analyses were performed using Statview and SAS statistical software (SAS Institute Inc., 1998, 2000).

\section{Characterization of Physical Measurements, Water Quality, Macroinvertebrates, and Habitat at Selected Sites}

Physical measurements, E. coli, nitrite plus nitrate, total phosphorus, and macroinvertebrate data collected from 2001 to 2003 were used to characterize the spatial distribution of these parameters at sampling sites. Data were examined in relation to watershed characteristics to determine if correlations were present between measures of urbanization and stream quality (physical measurements, water quality, habitat, and macroinvertebrates). 


\section{Physical Measurements and Water Quality}

Summary statistics from physical measurements for the study period are in table 2. Median instantaneous discharge ranged from 0.37 to $4.2 \mathrm{ft}^{3} / \mathrm{s}$. Continuous streamflow data are available at USGS gaging stations in the Seacoast region; however, the sites selected in this study did not contain USGS stations. The Oyster River at Durham, N.H., was used as an index gaging station to assist in characterizing streamflow conditions in the Seacoast region during the study. A comparison of the study data-collection-period streamflow to the historical data-collection period streamflow indicates that the study data-collection streamflow had below normal runoff (fig. 3). A comparison between daily mean streamflow for 2001-03 and the time during which water-quality samples were collected shows that most samples represent low-flow conditions, with some samples collected during spring snowmelt or rains, especially in 2002 and 2003 (fig. 4).

Median values of specific conductance ranged from 159 to $1,920 \mu \mathrm{S} / \mathrm{cm}$. Median $\mathrm{pH}$ ranged from 6.7 to 7.6 standard units and were within the water-quality criteria for $\mathrm{pH}$ (New Hampshire Department of Environmental Services, 2004). Median dissolved oxygen values ranged from 7.1 to $9.7 \mathrm{mg} / \mathrm{L}$ and were within water-quality criteria for dissolved oxygen (New Hampshire Department of Environmental Services, 2004). Measurements of $\mathrm{pH}$ and dissolved oxygen at the study sites did not exceed the magnitude of exceedances criteria (New Hampshire Department of Environmental Services, 2004). Median turbidity ranged from 1 to 8 NTUs at study sites during the study period. Median values of specific conductance (an indication of the dissolved ionic concentration) and turbidity (an indication of sediment or particulates) were elevated at sites with increased percentages of impervious surface in the watershed compared to sites with low percentages of impervious surface in the watershed, potentially indicating increased runoff from paved areas. The highest specific conductance $(4,060 \mu \mathrm{S} / \mathrm{cm})$ and turbidity (45 NTUs) values were found at site 7 (Paul Brook) and site 10 (Berry Brook), respectively (table 2).

Summary statistics for $E$. coli, nitrite plus nitrate, and total phosphorus, and the number of pesticide detections at study sites are listed in table 3 . Median $E$. coli concentrations ranged from 20 to $210 \mathrm{col} / 100 \mathrm{~mL}$, with maximum concentrations exceeding $2,000 \mathrm{col} / 100 \mathrm{~mL}$ at some sites. With the exception of site 5 (Parting Brook), at least one sample from all study sites exceeded the single sample maximum criteria for primary contact (swimming) for E. coli (New Hampshire Department of Environmental Services, 2004). However, median concentrations of $E$. coli at all sites were below the single sample maximum criteria. Median nitrite plus nitrate concentrations generally were low and ranged from 0.05 to $1.0 \mathrm{mg} / \mathrm{L}$. The highest nitrite plus nitrate concentration $(1.7 \mathrm{mg} / \mathrm{L})$ was found at site 8 (College Brook) (table 3). Median total phosphorus concentrations generally were low and ranged from 0.013 to $0.040 \mathrm{mg} / \mathrm{L}$. The highest total phosphorus concentration $(0.132 \mathrm{mg} / \mathrm{L}$ ) was found at site 5 (Parting Brook) (table 3). The number of pesticide detections ranged from 0 to 13 detections. The highest number of pesticide detections (11 and 13) were found at site 8 (College Brook) and site 9 (Reservoir Brook), respectively (table 3).

Generally, the lowest $E$. coli concentrations and nitrite plus nitrate yields were observed at sites with forest as the predominant land use in the watershed (figs. 5 and 6, respectively). Sampling sites having urban as the predominant land use in the watershed generally had elevated mean E. coli concentrations and nitrite plus nitrate yields. Other measurements, such as specific conductance and turbidity, showed similar patterns (table 2).

\section{Macroinvertebrates and Habitat}

Mean values for selected macroinvertebrate metrics are shown in table 4 . Total abundance at the sampling sites ranged from 885 to 6,321 organisms per $0.45 \mathrm{~m}^{2}$ and EPT abundance at the sampling sites ranged 62 to 1,499 organisms per 0.45 $\mathrm{m}^{2}$. Total taxa richness and EPT taxa richness at the sampling sites ranged from 11 to 25 and from 2 to 15 , respectively. Dominant taxon ranged from 38 to 60 percent at the sampling sites. The percent of one dominant taxon was greater at sites with urban as the predominant land use compared to sites with forest as the predominant land use (table 4). With the exception of percent dominant taxon, the selected macroinvertebrate community metrics generally decreased at sites with urban as the predominant land use compared to sites with forest as the predominant land use.

Generally, the highest EPT taxa richness values (from 6 to 15) were observed at sites with forest as the predominant land use in the watershed (fig. 7). Site 2 (Towle Brook) had the highest EPT taxa richness (table 4). Sampling sites with urban as the predominant land use in the watershed had lower mean EPT taxa richness (from 2 to 4 ) compared to the predominantly forested sites (fig. 7). Site 10 (Berry Brook) had the lowest EPT taxa richness (table 4).

General habitat quality was scored at each site using RBPs (Barbour and others, 1999). Eight of the study sites were rated as having optimal/suboptimal habitat, site 9 (Reservoir Brook) was rated as marginal habitat and site 4 (Parkman Brook) was rated as poor habitat (table 4) primarily as a result of modifications to the stream channel. Optimal/suboptimal habitat was considered suitable conditions for biological communities at sampled sites. Marginal and poor habitat was considered less than desirable conditions for biological communities at sampled sites. The habitat scores were used to represent the qualitative habitat conditions at sampling sites and are reflected in the WQHS. 

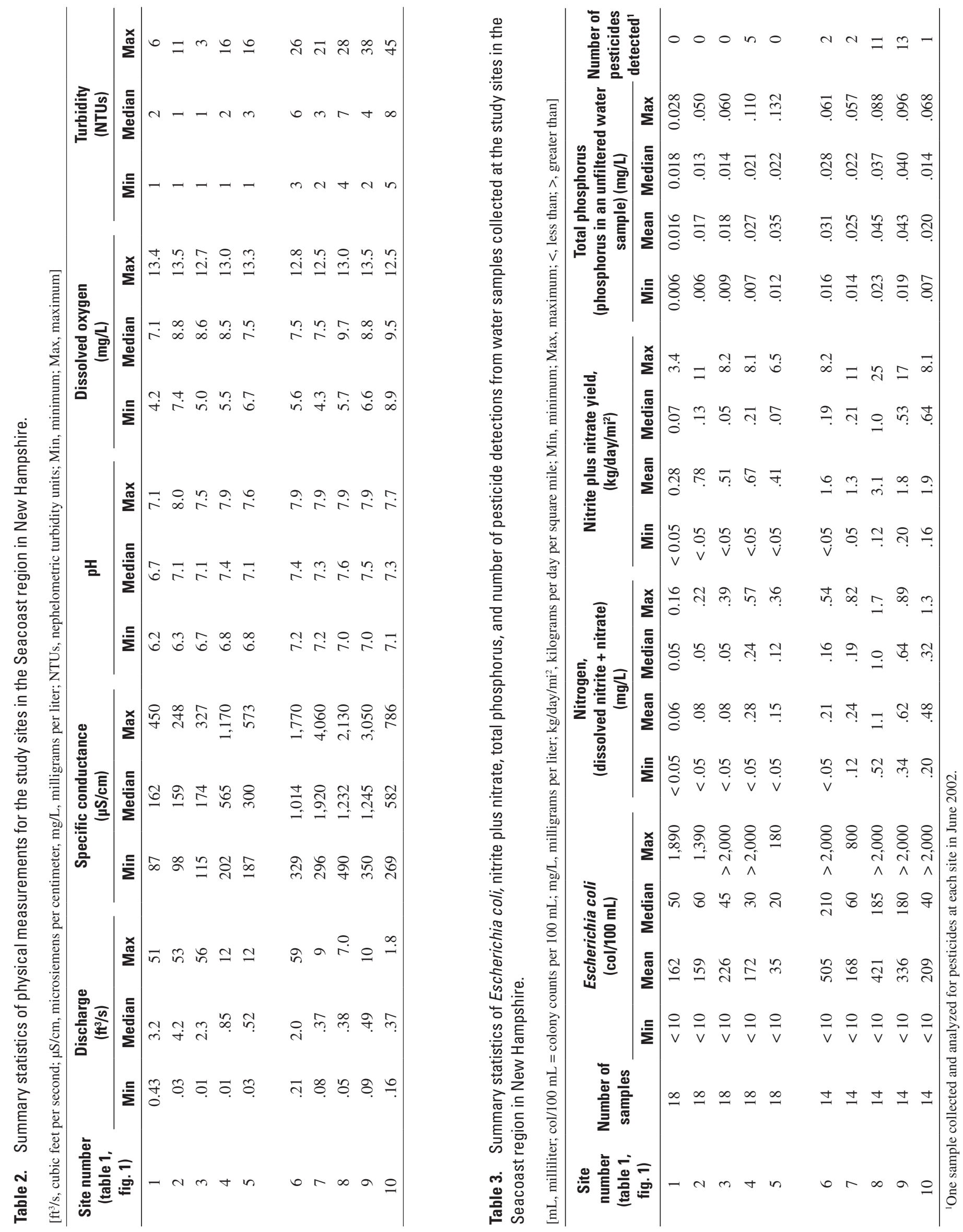


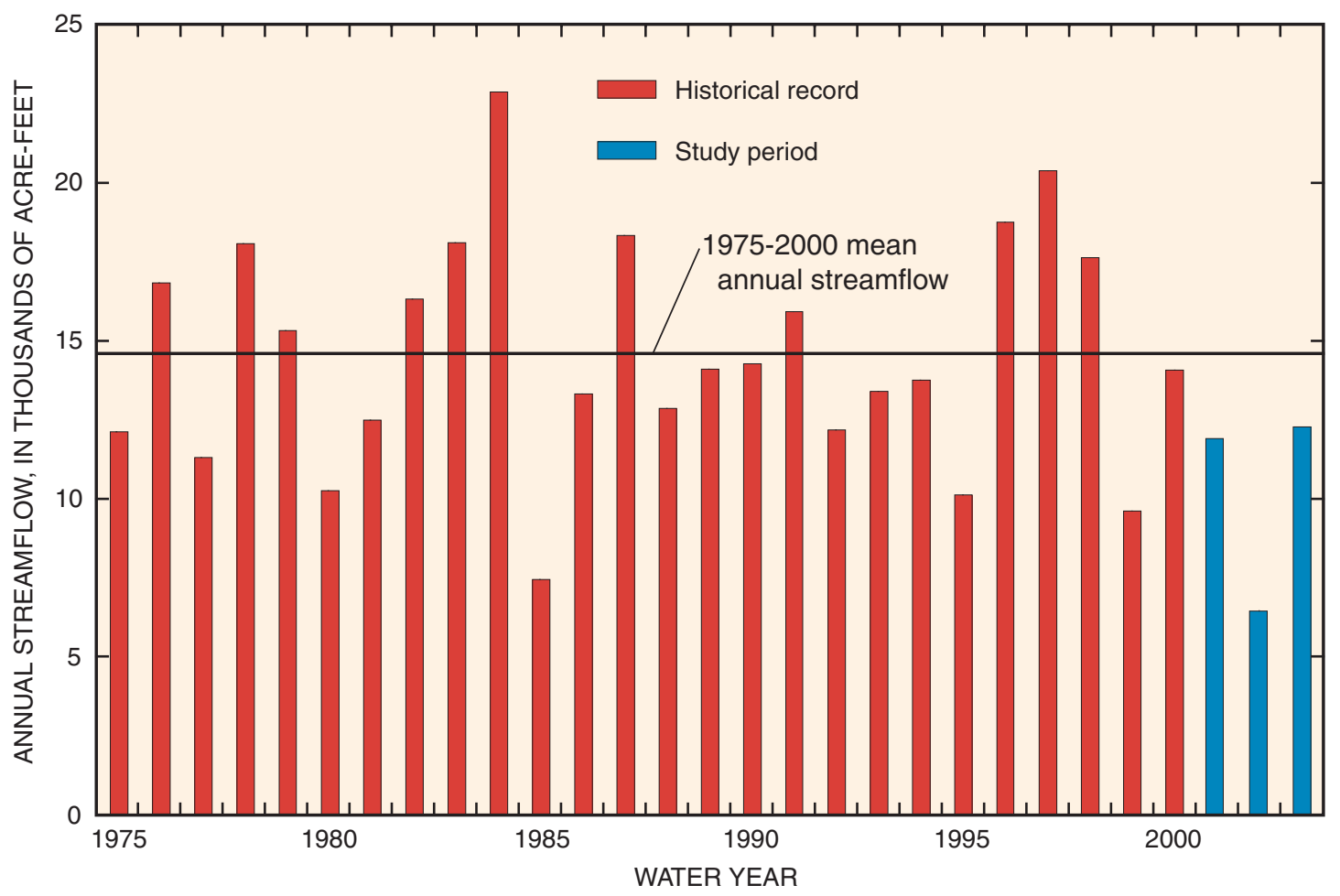

Figure 3. Mean annual streamflow for historical and study period years from the Oyster River at Durham, N.H. (used as an index gaging station for the study area).

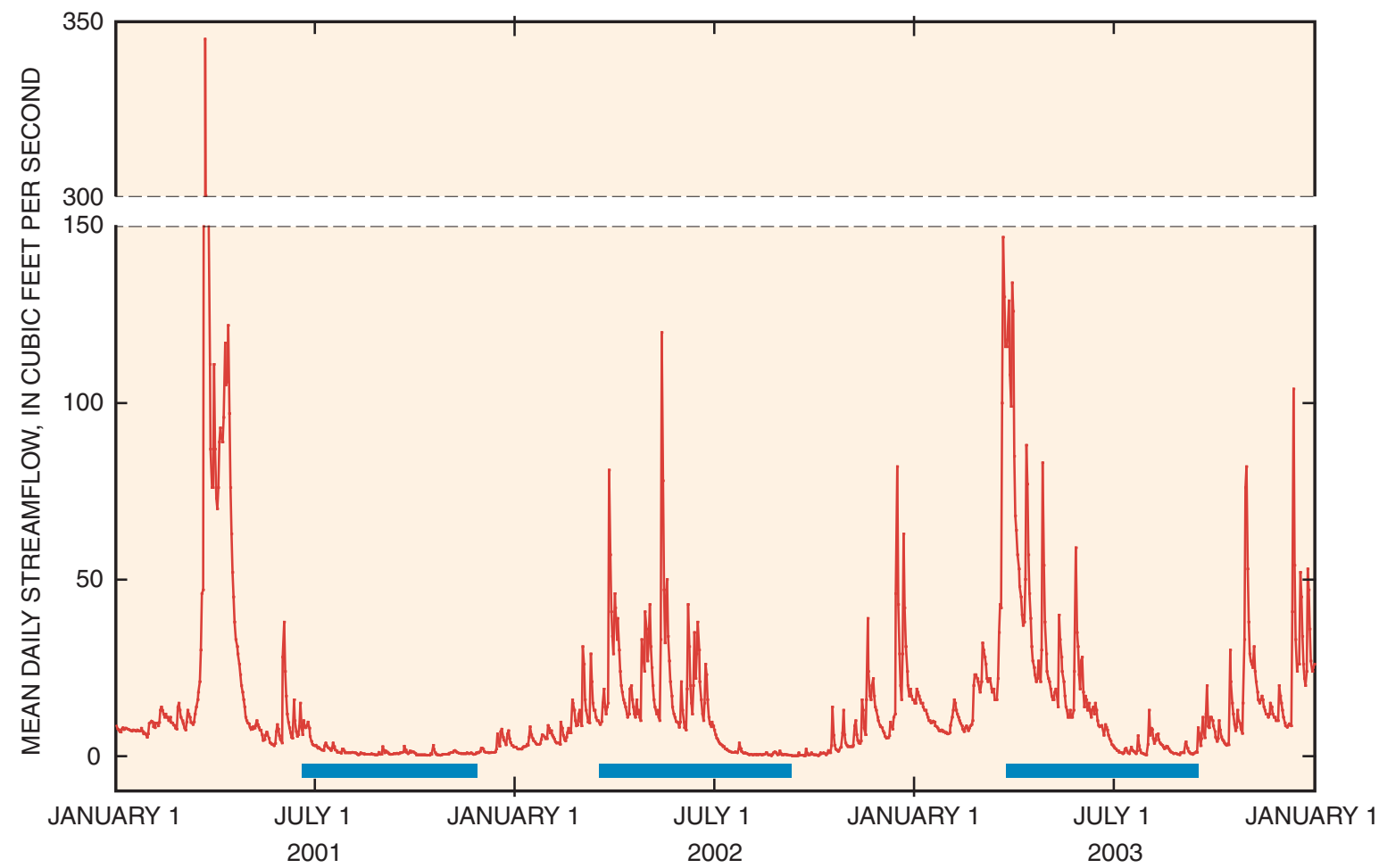

Figure 4. Hydrograph of mean daily streamflow for water years 2001-03 from the Oyster River at Durham, N.H. (used as an index gaging station for the study area). The blue bars represent the general streamflow characteristics in the Seacoast region during the water-quality sampling period. 


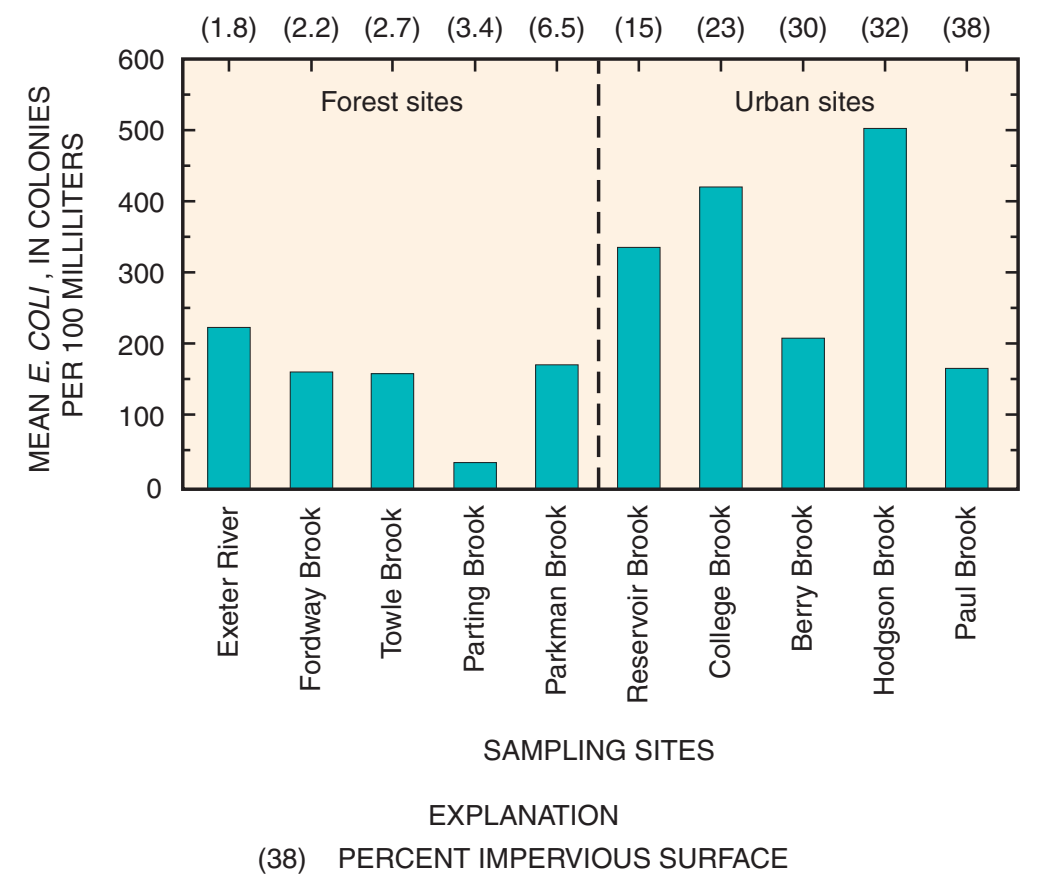

Figure 5. Mean Escherichia coli (E. coli) concentrations among sampling sites, predominant land use, and percentage of impervious surface at study sites in the Seacoast region of New Hampshire. (Refer to table 1 and figure 1 for site numbers and locations of sampling sites.)

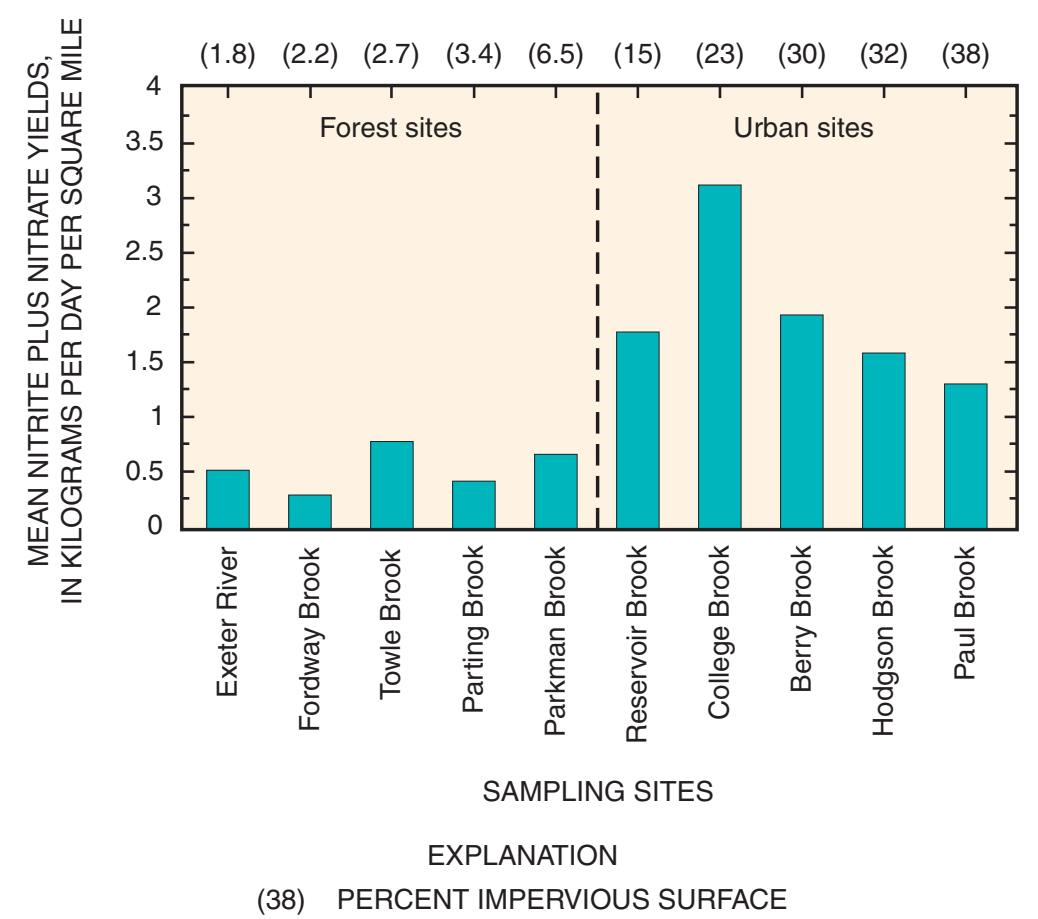

Figure 6. Mean nitrite plus nitrate yields among sampling sites, predominant land use, and percentage of impervious surface at study sites in the Seacoast region of New Hampshire. (Refer to table 1 and figure 1 for site numbers and locations of sampling sites). 
Table 4. Mean values of selected macroinvertebrate metrics for samples collected at each of the study sites in the Seacoast region in New Hampshire.

[EPT, Ephemeroptera, Plecoptera, Tichoptera; $\mathrm{m}^{2}$, square meters]

\begin{tabular}{|c|c|c|c|c|c|c|}
\hline $\begin{array}{c}\text { Site number } \\
\text { (table 1; fig. 1) }\end{array}$ & $\begin{array}{c}\text { Total } \\
\text { abundance }^{1}\end{array}$ & $\begin{array}{c}\text { EPT } \\
\text { abundance }^{1}\end{array}$ & $\begin{array}{l}\text { Total taxa } \\
\text { richness }^{2}\end{array}$ & $\begin{array}{l}\text { EPT taxa } \\
\text { richness }^{2}\end{array}$ & $\begin{array}{c}\text { Percent } \\
\text { dominant taxon }\end{array}$ & $\begin{array}{l}\text { Habitat } \\
\text { score }^{3}\end{array}$ \\
\hline \multicolumn{7}{|c|}{ Forest sites } \\
\hline 1 & 3,503 & 1,499 & 19 & 10 & 42 & 150 \\
\hline 2 & 4,922 & 818 & 25 & 15 & 42 & 147 \\
\hline 3 & 1,786 & 444 & 18 & 10 & 41 & 154 \\
\hline 4 & 6,321 & 567 & 21 & 6 & 40 & 45 \\
\hline 5 & 3,762 & 1,074 & 21 & 8 & 38 & 105 \\
\hline Mean & 4,059 & 4,402 & 21 & 10 & 41 & 120 \\
\hline \multicolumn{7}{|c|}{ Urban sites } \\
\hline 6 & 1,143 & 602 & 16 & 4 & 57 & 101 \\
\hline 7 & 2,204 & 371 & 14 & 3 & 55 & 112 \\
\hline 8 & 3,515 & 666 & 13 & 3 & 56 & 131 \\
\hline 9 & 5,294 & 680 & 11 & 3 & 60 & 64 \\
\hline 10 & 885 & 62 & 13 & 2 & 59 & 112 \\
\hline Mean & 2,608 & 476 & 13 & 3 & 57 & 104 \\
\hline
\end{tabular}

${ }^{1}$ Number of organisms per $0.45 \mathrm{~m}^{2}$.

${ }^{2}$ Number of taxa per $0.45 \mathrm{~m}^{2}$.

${ }^{3}$ Habitat scores of 0-50, poor habitat rating; 51-100, marginal habitat rating; 101-150, suboptimal habitat rating; 151-200, optimal habitat rating.
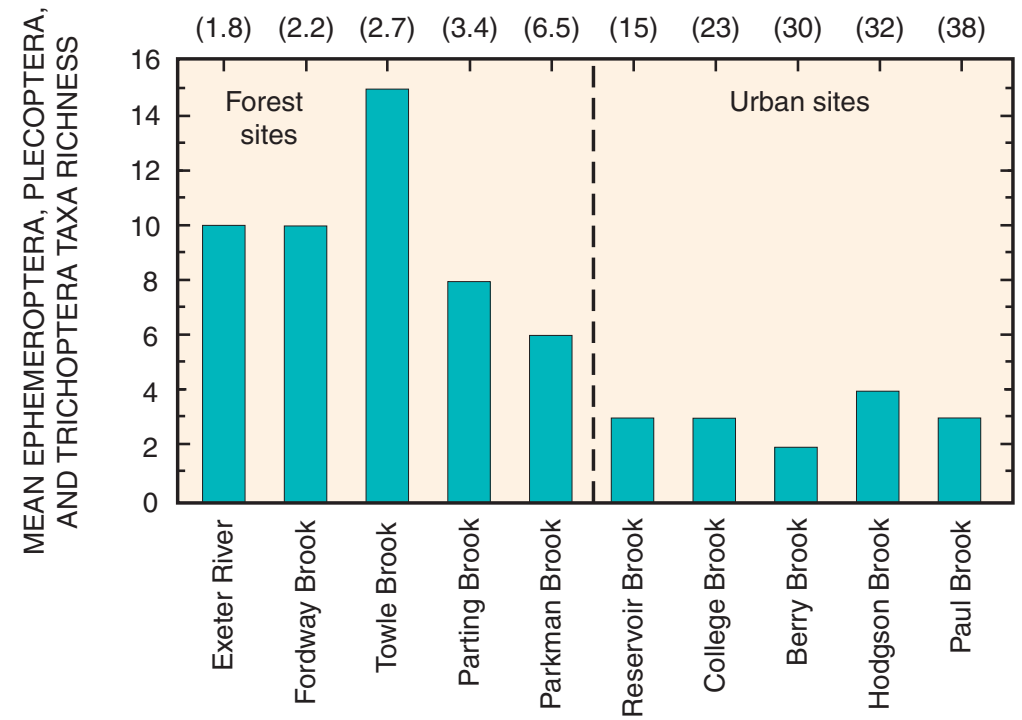

SAMPLING SITES

EXPLANATION

(38) PERCENT IMPERVIOUS SURFACE

Figure 7. Mean value for Ephemeroptera, Plecoptera, and Trichoptera taxa richness among sampling sites, predominant land use, and percentage of impervious surface at study sites in the Seacoast region of New Hampshire. (Refer to table 1 and figure 1 for site numbers and locations of sampling sites). 


\section{Effects of Urbanization on Stream Quality at Selected Sites}

The degraded character of streams typically does not result from any single factor, but rather from the interaction of various effects (Klein, 1979). Although the exact point at which stream quality and macroinvertebrate communities shift from good to poor is not known with precision, increased urbanization within a watershed does result in degraded water quality and a less diverse macroinvertebrate community (Schueler, 1994; Jones and Clark, 1987).

Specific conductance, turbidity, nitrite plus nitrate yields, and selected macroinvertebrate community data were significantly correlated with most measures of urbanization used in this study (table 5). E. coli concentrations and total phosphorus yields were not statistically correlated with most measures of urbanization in this study (table 5). Measures of urbanization that generally had the highest correlations with stream-quality variables were associated with the percent of urban land in buffer zones upstream of the sampling site (table 5). Specifically, the percent of urban land use in a $1-\mathrm{km}$ radial buffer and the percent of urban land use in a $25-\mathrm{m}$ stream buffer generally had higher correlation coefficients with stream-quality variables than other urban stream-buffer variables and stream-quality variables (table 5 ).

Table 5. Summary of Spearman rank correlations between watershed characteristics and stream-quality variables at the study sites in the Seacoast region in New Hampshire.

[E. coli, Escherichia coli; col/100 ml, colony counts per 100 milliliters; $\mathrm{kg} / \mathrm{day} / \mathrm{mi}^{2}$, kilograms per day per square mile; EPT, Ephemeroptera, Plecoptera, Trichoptera; WQHS, water-quality and habitat conditions score; BCS, biological condition score; NS, is not statistically significant at $a=0.05$, all other relations were statistically significant; $\mathrm{km}$, kilometers; $\mathrm{m}$, meters]

\begin{tabular}{|c|c|c|c|c|c|c|c|c|c|c|}
\hline $\begin{array}{c}\text { Watershed } \\
\text { characteristics }\end{array}$ & $\begin{array}{c}\text { Specific } \\
\text { conduc- } \\
\text { tance }\end{array}$ & Turbidity & $\begin{array}{c}\text { E. coli } \\
\text { (col/100mL) }\end{array}$ & $\begin{array}{l}\text { Nitrite plus } \\
\text { nitrate yield } \\
(\mathrm{kg} / \text { day/mi) }\end{array}$ & $\begin{array}{l}\text { Total phospho- } \\
\text { rus yield } \\
\left(\mathrm{kg} / \mathrm{day} / \mathrm{mi}^{2}\right)\end{array}$ & $\begin{array}{l}\text { Species } \\
\text { richness }\end{array}$ & $\begin{array}{c}\text { EPT } \\
\text { richness }\end{array}$ & $\begin{array}{l}\text { Percent } \\
\text { dominant } \\
\text { taxon }\end{array}$ & WOHS & BCS \\
\hline \multicolumn{11}{|c|}{ Infrastructure variables ${ }^{1}$} \\
\hline Impervious surface & 0.84 & 0.78 & NS & 0.74 & NS & NS & -0.75 & NS & -0.70 & -0.75 \\
\hline Road density & .70 & .95 & NS & .81 & NS & -0.68 & -.81 & 0.72 & -.82 & -.88 \\
\hline Population density & NS & .72 & NS & .64 & NS & NS & -.66 & NS & -.75 & -.77 \\
\hline Urban & 0.71 & 0.85 & NS & 0.74 & NS & NS & -0.74 & NS & -0.68 & -0.79 \\
\hline Forest & -.67 & -.70 & NS & -.67 & NS & NS & .70 & -0.66 & .64 & .74 \\
\hline \multicolumn{11}{|c|}{ Radial-buffer variables ${ }^{3}$} \\
\hline Urban-0.5 km & 0.70 & 0.87 & NS & 0.90 & NS & -0.70 & -0.88 & 0.73 & -0.85 & -0.92 \\
\hline Urban-1 km & .76 & .95 & NS & .92 & NS & -.78 & -.89 & .76 & -.86 & -.94 \\
\hline \multicolumn{11}{|c|}{ Stream-buffer variables ${ }^{4}$} \\
\hline Urban-25 m & 0.65 & 0.92 & 0.35 & 0.86 & NS & -0.68 & -0.80 & 0.73 & -0.80 & -0.86 \\
\hline Urban-100 m & .66 & .90 & NS & .82 & NS & -.69 & -.77 & .83 & -.77 & -.82 \\
\hline Urban-250 m & .67 & .89 & NS & .81 & NS & -.65 & -.74 & .78 & -.71 & -.79 \\
\hline Forest- $25 \mathrm{~m}$ & NS & -.66 & NS & -.68 & NS & NS & NS & -.78 & .67 & .68 \\
\hline Forest-100 m & NS & -.79 & NS & -.72 & NS & NS & .66 & -.79 & .70 & .73 \\
\hline Forest- $250 \mathrm{~m}$ & -.65 & -.85 & NS & -.79 & NS & .71 & .76 & -.86 & .75 & .80 \\
\hline
\end{tabular}

${ }^{1}$ Impervious surface, the percent of impervious surface in the watershed; Road density, road density in watershed [road length (kilometer)/watershed area (square kilometer)]; Population density, population density, 2000 [people per square mile].

${ }^{2}$ Urban, the percent of urban land in the entire watershed; Forest, the percent of forest land in the entire watershed..

${ }^{3}$ Urban- $0.5 \mathrm{~km}$, the percent of urban land within a $0.5-\mathrm{km}$ radius of the sampling site; Urban- $1 \mathrm{~km}$, the percent of urban land within a 1-km radius of the sampling site; Urban- $2 \mathrm{~km}$, the percent of urban land within a 2-km radius of the sampling site; Forest $-0.5 \mathrm{~km}$, the percent of forest land within a $0.5-\mathrm{km}$ radius of the sampling site; Forest- $1 \mathrm{~km}$, the percent of forest land within a 1-km radius of the sampling site; Forest-2 km, the percent of forest land within a $2-\mathrm{km}$ radius of the sampling site.

${ }^{4}$ Urban- $25 \mathrm{~m}$, the percent of stream buffer (25 m) area in urban land use; Urban-100 m, the percent of stream buffer (100 m) area in urban land use; Urban$250 \mathrm{~m}$, the percent of stream buffer $(250 \mathrm{~m})$ area in urban land use; Forest- $25 \mathrm{~m}$, the percent of stream buffer $(25 \mathrm{~m})$ area in forest land use; Forest- $100 \mathrm{~m}$, the percent of stream buffer $(100 \mathrm{~m})$ area in forest land use; Forest- $250 \mathrm{~m}$, the percent of stream buffer $(250 \mathrm{~m})$ area in forest land use. 


\section{Impervious Surface and Stream-Quality Measures}

There appears to be a level (between 7 and 14 percent impervious surface) at which water-quality and habitat site rankings become affected by urban characteristics such as impervious surface. This result is similar to other studies, where measures of the impervious surface area of about 10 percent have been identified as the level at which stream quality decreases (Klein, 1979; Schueler, 1994; Booth and Reinelt, 1993). In this study, a negative correlation was found between the WQHS and the percent of impervious surface in the upstream watershed of the sampled sites $(r=-0.70$; $\mathrm{p}<0.05$ ). The WQHS decreased with increased percent of impervious surface (fig. 8a).

The biological condition score also appears to be affected by the level of impervious surface area in the watershed. A negative correlation was found between the BCS and the percent of impervious surface in the upstream watershed of the sampled sites $(r=-0.75 ; p<0.05)$. The BCS decreased with increased percent of impervious surface in the watershed at sampled sites (fig. 8b). These results are similar to the relation between the WQHS and the percent of impervious surface in a watershed in that there appears to be a level (between 7 and 14 percent impervious surface) at which the biological condition of a site becomes affected by urban characteristics.

To determine the response of EPT taxa richness to measures of urbanization, mean EPT taxa richness was plotted against the percent of impervious surface (fig. 8c). A negative correlation was found between EPT taxa richness and the percent of impervious surface $(r=-0.75 ; p<0.01)$ (table 5). The response of this single metric to the percent of impervious surface in a watershed is similar to the response of the multi-metric (BCS) to the percent of impervious surface in the watershed. This similarity indicates that EPT taxa richness may be used to evaluate effects of urban land use on small streams in this region. Other studies also have reported that EPT taxa were responsive to the intensity of urbanization in a watershed (Ourso and Frenzel, 2003; Coles and others, 2004).

\section{Radial Buffers and Stream-Quality Measures}

Stream quality, when measured by the WQHS, the BCS, and EPT taxa richness, decreased as the percent of urban land use increased in a 1-km radial buffer of the sampling site (fig. 9). The highest correlation coefficients between the radial-buffer variables and the WQHS and BCS were for the percent of urban land in a 1-km radial buffer. The percent of urban land in a 1-km radial buffer was negatively correlated with the WQHS $(r=-0.86 ; p<0.001)$ and this correlation was higher than correlations between the percent of impervious surface and the WQHS $(r=-0.70 ; p<0.05)$ and between the percent of urban land use in the entire watershed and the WQHS $(r=-0.68 ; p<0.05)($ table 5$)$.

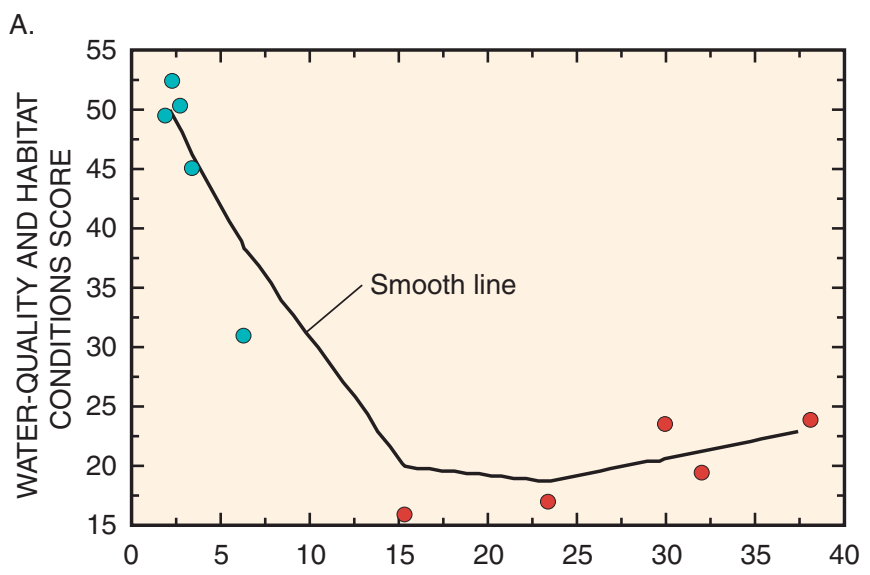

B.

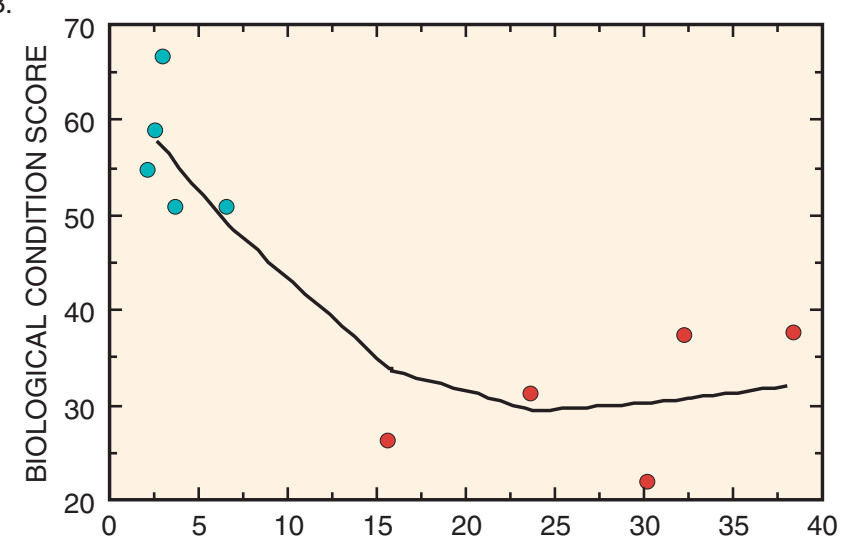

C.

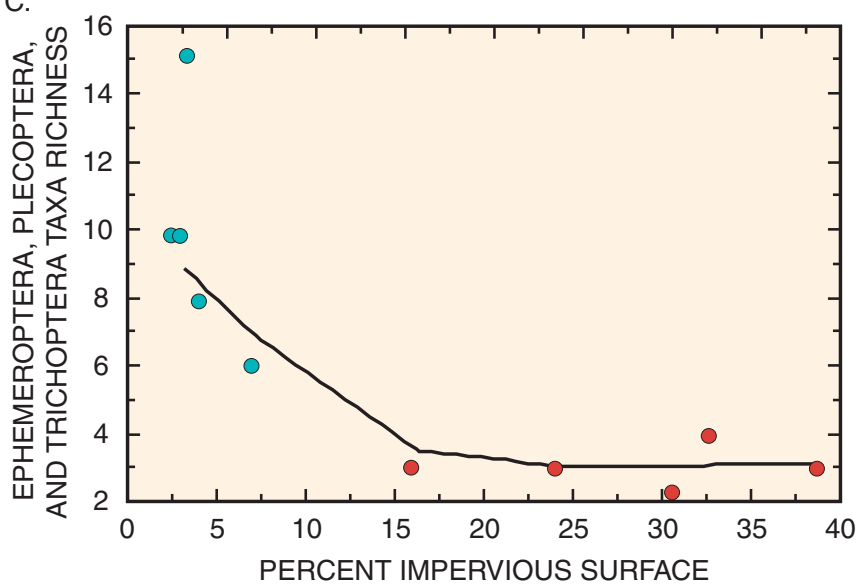

EXPLANATION

SITE TYPE

- Forest sites

- Urban sites

Figure 8. Relation between the percent of impervious surface in the watershed and the (A) water-quality and habitat conditions score, (B) biological condition score, and (C) mean Ephemeroptera, Plecoptera, and Trichoptera taxa richness at the study sites in the Seacoast region in New Hampshire. [smooth line, locally weighted scatterplot smoothing] 
A.

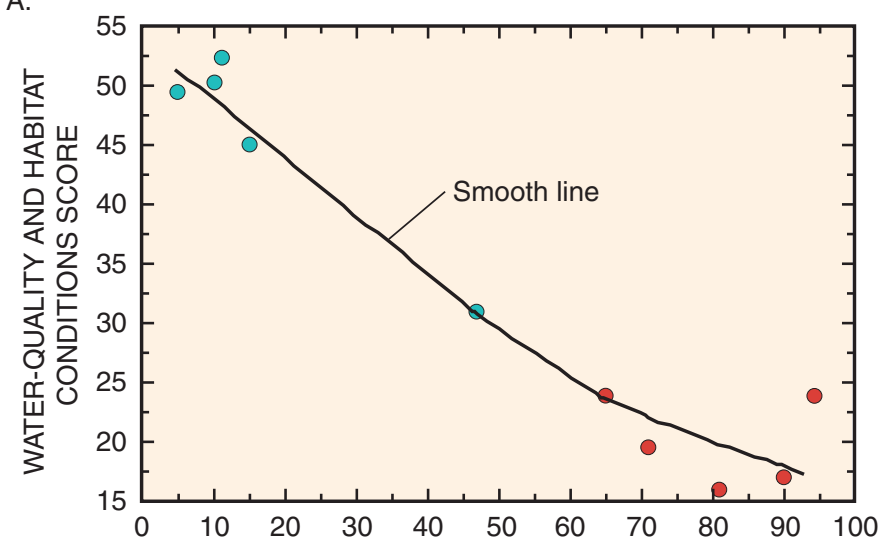

B.

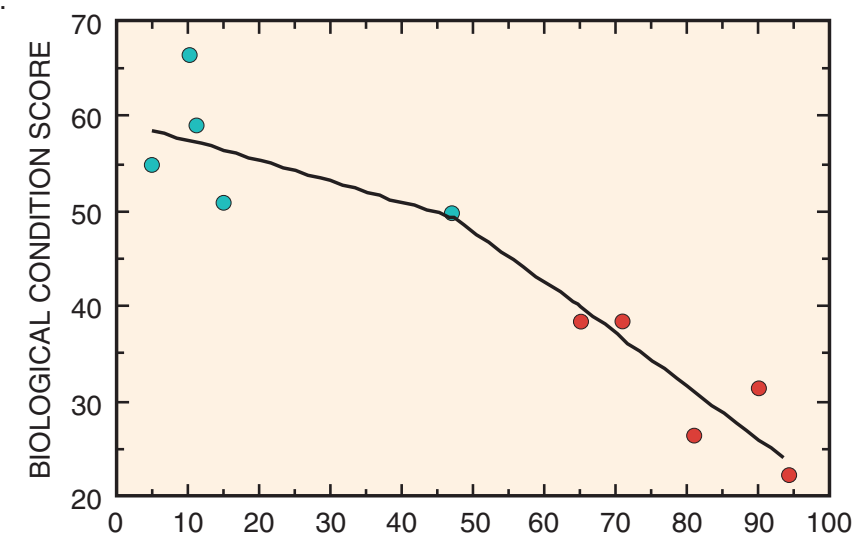

C.

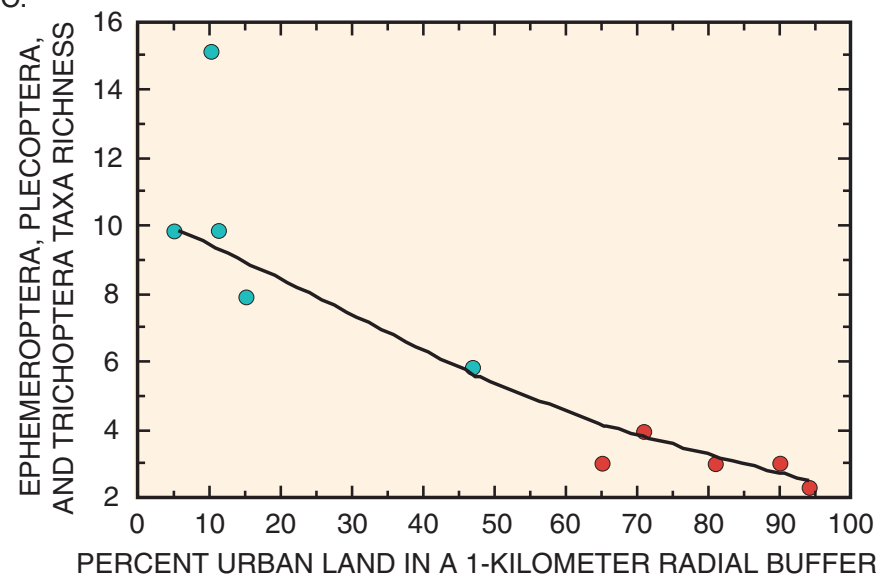

EXPLANATION

SITE TYPE

- Forest sites

- Urban sites

Figure 9. Relation between the percent of urban land in a 1-kilometer radial buffer and the $(A)$ water-quality and habitat conditions score, (B) biological condition score, and (C) mean Ephemeroptera, Plecoptera, and Trichoptera taxa richness at the study sites in the Seacoast region in New Hampshire [smooth line, locally weighted scatterplot smoothing
The WQHS decreased with increased percent of urban land in the 1-km radial buffer (fig. 9a). The relation between these two variables indicates a change in water-quality and habitat conditions at sites with increased percent of urban land in the $1-\mathrm{km}$ radial buffer. In contrast, a positive correlation was found between the percent of forest land in the $1-\mathrm{km}$ radial buffer and the WQHS $(r=0.89 ; \mathrm{p}<0.001)$. The percent of forest land in other radial-buffer variables and the entire watershed also showed positive correlations with the WQHS (table 5). Forest land use typically reduces runoff of water, sediments, nutrients, and other constituents and provides more organic material and debris to the stream as food supply for aquatic life (Wang and other, 1997). The positive correlations between the forested characteristics in the upstream watershed and the WQHS indicates that forested riparian areas may be important in maintaining water-quality and habitat conditions.

The percent of urban land in a 1-km radial buffer of the sampling site was negatively correlated with the BCS $(\mathrm{r}=-0.94 ; \mathrm{p}<0.0001)$ and this correlation was higher than correlations between the percent of impervious surface and the BCS $(r=-0.75 ; p<0.05)$ and between the percent of urban land use in the entire watershed and the BCS ( $\mathrm{r}=-0.79$; $\mathrm{p}<0.01)$ (table 5). The BCS decreased with increased percent of urban land in the 1-km radial buffer (fig. 9b). The relation between these two variables indicates a change in the macroinvertebrate community structure at sites with increased percent of urban land in the 1-km radial buffer. Various other studies have also shown that urban development affects macroinvertebrate communities (Benke and others, 1981; Garie and McIntosh, 1986; Coles and others, 2004). In contrast, a positive correlation was found between the percent of forest land in the $1-\mathrm{km}$ radial buffer and the BCS $(\mathrm{r}=0.93$; $\mathrm{p}<0.0001)$. The percent of forest land in other radial- and stream-buffer variables and the entire watershed also showed significant positive correlations with the BCS (table 5). These correlations indicate that the macroinvertebrate community may be affected by the percent and type of vegetation near the sampling site and that these data appear to discriminate urbanization effects on stream quality at sampled sites in this study. These results are in agreement with those of previous studies (Coles and others, 2004; Jones and Clark, 1987; Lenat and Crawford, 1994).

To determine the response of EPT taxa richness to urbanization, mean EPT taxa richness was plotted against the percent of urban land in the 1-km radial buffer (fig. 9c). The response of this single metric to the percent of urban land in the $1-\mathrm{km}$ radial buffer is similar to the response of the multimetric (BCS) to the percent of urban land in the $1-\mathrm{km}$ radial buffer.

\section{Stream Buffers and Stream-Quality Measures}

Stream quality, when measured by the WQHS, the BCS, and EPT taxa richness, decreased as the percent of urban land use increased in a stream buffer along the stream corridor, upstream of a sampling site (fig. 10). The percent of urban 
land in this $25-\mathrm{m}$ stream buffer area had higher correlations with the WQHS $(r=-0.80 ; p<0.01)$ than correlations between the percent of urban land in a $100-\mathrm{m}$ and $250-\mathrm{m}$ stream buffer, the percent of impervious surface, and the percent of urban land use in the entire watershed with the WQHS. The WQHS decreased with increased percent of urban land in a $25-\mathrm{m}$ stream buffer (fig. 10a).

When the percent of urban land increased in a $25-\mathrm{m}$ stream buffer upstream the BCS decreased (fig. 10b). The percent of urban land in a 25-m stream buffer had higher correlations with the BCS $(r=-0.86 ; p<0.01)$ than correlations between the percent of urban land in a 100-m and $250-\mathrm{m}$ stream buffer, the percent of impervious surface, and the percent of urban land use in the entire watershed with the BCS. The relation between these two variables indicates a change in the macroinvertebrate community structure at sites with increased percent of urban land in a 25-m stream buffer.

To determine the response of EPT taxa richness to measures of urbanization, mean EPT taxa richness was plotted against the percent of urban land in a 25-m stream buffer (fig. 10c). A negative correlation was found between EPT taxa richness and the percent of urban land in a 25-m stream buffer $(\mathrm{r}=-0.80 ; \mathrm{p}<0.01)($ table 5$)$.

In contrast to these results described above, the highest correlation between the percent of forest land use and the WQHS $(r=0.75 ; p<0.05)$ and the BCS $(r=0.80$; $\mathrm{p}<0.05$ ) was for a $250-\mathrm{m}$ stream buffer, compared to the $25-\mathrm{m}$ or $100-\mathrm{m}$ stream buffers (table 5 ). These results indicate that the increased width of a forested area along the stream corridor may result in improved stream quality. These results also indicate that watersheds with urban land along a stream corridor may be subject to greater stream-quality degradation than watersheds with forested land along a stream corridor. May and others (1997) report similar findings on small streams in the Puget Sound ecoregion where stream buffers are important and play a key role in mitigating effects from watershed development.

\section{Water-Quality and Habitat Conditions Score and the Biological Condition Score}

The WQHS and the BCS generally follow a similar relation to one another with the measures of urbanization in a watershed. The WQHS and the BCS were correlated $(\mathrm{r}=0.89 ; \mathrm{p}<0.01)$. The relation between the WQHS and the BCS indicates that sampling sites with high scores for waterquality and habitat conditions also had high scores for the biological condition (fig. 11). The scores show that the ranks of general water-quality and habitat (WQHS) follow a similar pattern as the ranks of the biological metrics (BCS) and high scores indicate improved stream quality at a sampling site.

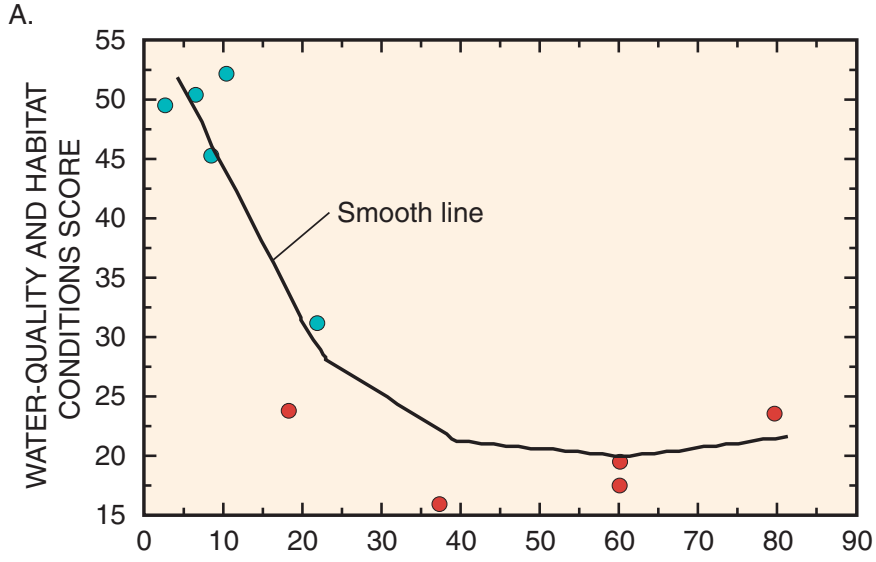

B.

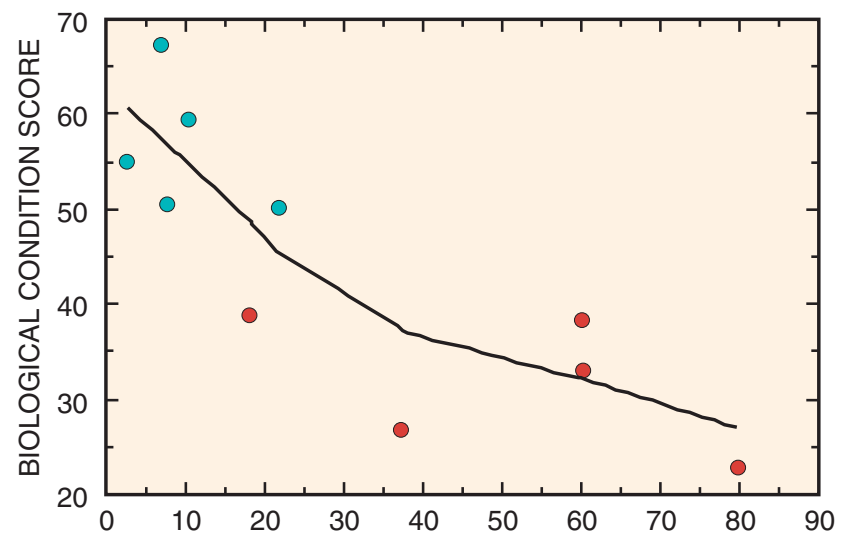

C.

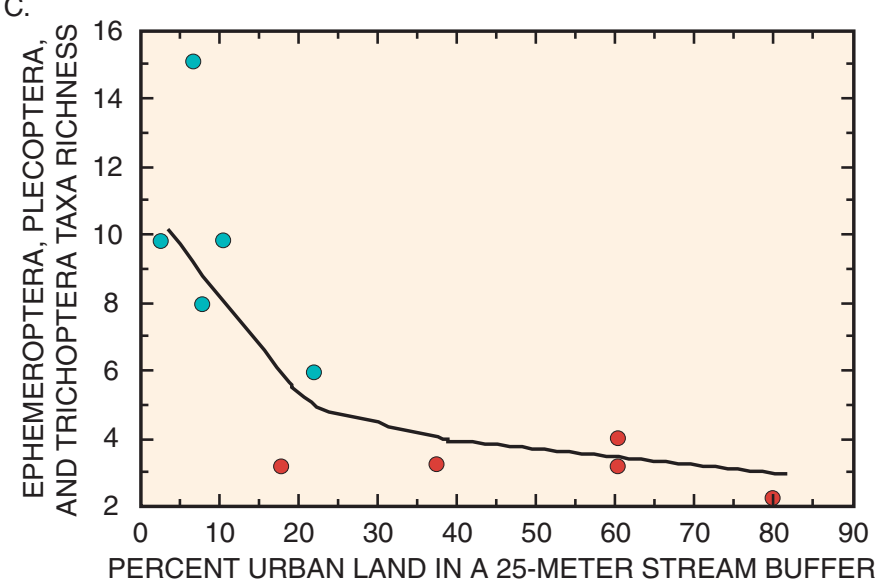

EXPLANATION

SITE TYPE

- Forest sites

- Urban sites

Figure 10. Relation between the percent of urban land in a 25-meter stream buffer and the (A) water-quality and habitat conditions score, (B) biological condition score, and (C) mean Ephemeroptera, Plecoptera, and Trichoptera taxa richness at the study sites in the Seacoast region in New Hampshire [smooth line, locally weighted scatterplot smoothing]. 


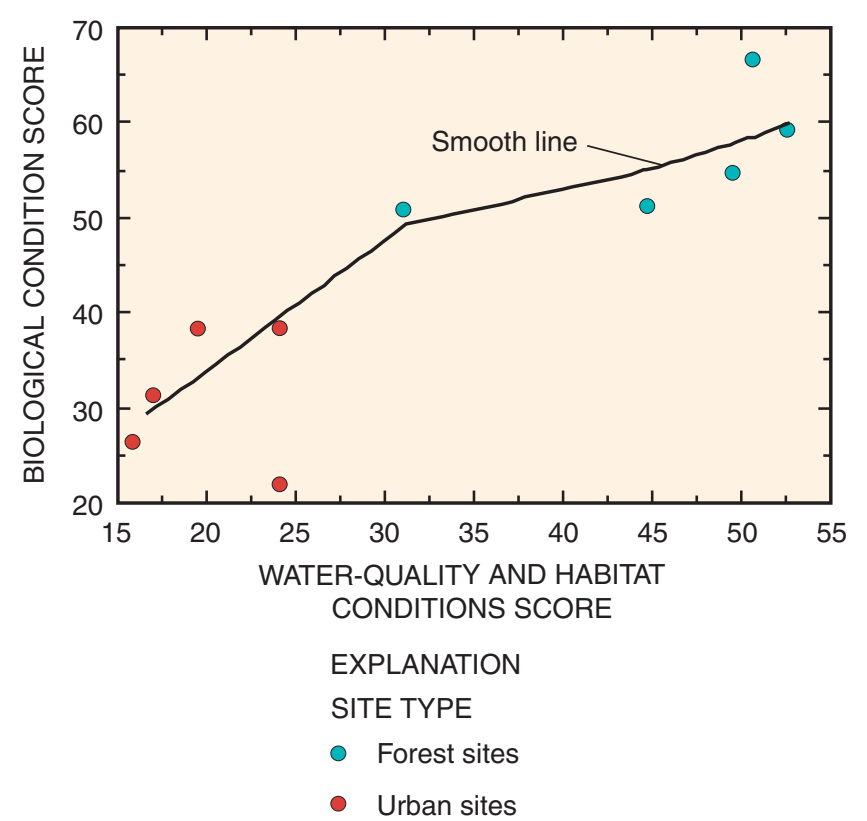

Figure 11. Relation between the water-quality and habitat conditions score and the biological condition score at the study sites in the Seacoast region in New Hampshire [smooth line, locally weighted scatterplot smoothing].

\section{Summary and Conclusions}

Concentrations of selected chemical constituents and macroinvertebrate community data collected from small streams in the Seacoast region of New Hampshire were evaluated in relation to the intensity of urbanization in a watershed. Water-quality samples were collected from 10 stream sites during the spring, summer, and fall seasons from 2001 to 2003 and analyzed for $E$. coli, nitrite plus nitrate, and total phosphorus. Macroinvertebrate samples were collected once each year during low-flow conditions and analyzed for identification and enumeration. The U.S. Geological Survey, in cooperation with the New Hampshire Department of Environmental Services Coastal Program, designed this study to determine the degree to which urbanization affects stream quality in the Seacoast region.

Concentrations of selected chemical constituents were found to be higher in watersheds with high percent of impervious surface than in watersheds with low percent of impervious surface. Chemical concentrations in watersheds with the lowest percentages of impervious surface had the lowest concentrations of all detectable constituents. Specific conductance, turbidity, nitrite plus nitrate yields, and selected macroinvertebrate community data were significantly correlated with most measures of urbanization used in this study, whereas E. coli concentrations and total phosphorus yields were not statistically correlated with most measures of urbanization in this study. Generally, the highest median and maximum values of the analyzed water-quality constituents were found at sites with a high percent of impervious surface and urban land in the watershed. The macroinvertebrate data also showed changes in relation to the percent of impervious surface and urban land use among sampling sites. Streams draining predominantly forested watersheds generally were characterized by higher abundance and taxa richness in the macroinvertebrate community than streams draining predominantly urban watersheds.

The correlations between the percent of urban land use in a 1-km radial buffer of the sampling site and the water-quality and habitat conditions score and the biological condition score were higher than correlations between other radial- and stream-buffer variables, the percent of impervious surface, and the percent of urban land in the entire watershed with these same indicators of stream quality. The measures of stream quality (water-quality and habitat conditions score, biological condition score, and EPT taxa richness) at sampled sites were negatively related to the percent of urban land and positively related to the percent of forest land upstream from a sampling site. Watershed urbanization appeared to have caused noticeable changes in the stream quality at sampled sites. Another key variable affecting stream quality was the quantity and quality of a stream buffer. Specifically, radial or stream buffers dominated by forested land appear to help maintain a better level of stream quality than radial or stream buffers dominated by urban land.

In this study, sites with greater than 14-percent impervious surface in a watershed generally showed changes in stream quality as measured by a water-quality and habitat conditions score and a biological condition score. Results from this study also indicate that the percent of urban land use in streambuffer areas generally were valuable indicators of stream quality. Ongoing water-quality or stream-biota monitoring of these small streams in the Seacoast region will be important to assess the effects of continued urban development in southeastern New Hampshire.

\section{Acknowledgments}

The authors acknowledge the effort provided by Ted Diers, New Hampshire Department of Environmental Services Coastal Program, and Joanne McLaughlin (formerly of the New Hampshire Coastal Program) for their assistance in the collection of data and project development and support. Thanks are extended to Kenneth Gallagher, New Hampshire Office of Energy and Planning; Fay Rubin, University of New Hampshire; and Laura Hayes, U.S. Geological Survey, for their geographic information systems assistance. Thanks are also extended to Melissa Riskin, U.S. Geological Survey, for her assistance in collection of water-quality samples and streamflow measurements and Philip Trowbridge, New Hampshire Department of Environmental Services, and Tim Brabets, U.S. Geological Survey, for their critical review 
of this report. Appreciation is extended to Debra Foster for the editorial report review and manuscript and layout, and Anita Cotton for graphics.

\section{Literature Cited}

Barbour, M.T., Gerritsen, B.D., Snyder, B.D., and Stribling, J.B., 1999, Rapid bioassessment protocols for use in streams and wadeable rivers: Periphyton, benthic macroinvertebrates and fish, (2d ed): Washington, D.C., U.S. Environmental Protection Agency, Office of Water, EPA 841-B-99-002, variously paged.

Benke, A.C., Willke, F.K., Parrish, F.K., Stites, D.L., 1981, Effects of urbanization on stream ecosystems: Atlanta, Ga., Georgia Institute of Technology, ERC07-81, 64 p.

Booth, D.B., and Reinelt, L.E., 1993, Consequences of urbanization on aquatic systems - measured effects, degradation thresholds, and corrective strategies, in Proceedings of the Watershed 1993 Conference: U.S. Environmental Protection Agency, Washington D.C., U.S. Government Printing Office, p. 545-550.

Coles, J.F., Cuffney, T.F., McMahon, G., and Beaulieu, K.M., 2004, The effects of urbanization on the biological, physical, and chemical characteristics of coastal New England streams: U.S. Geological Survey Professional Paper 1695, $47 \mathrm{p}$.

Cuffney, T.F., Gurtz, M.E., and Meador, M.R., 1993, Methods for collecting benthic invertebrate samples as part of the National Water-Quality Assessment Program: U.S. Geological Survey Open-File Report 93-406, 66 p.

Dufour, A.P., 1984, Health effects criteria for fresh recreational waters: Cincinnati, Ohio, U.S. Environmental Protection Agency, EPA-600/1-84-004, 33 p.

Garie, H.L., and McIntosh, A., 1986, Distribution of benthic macroinvertebrates in a stream exposed to urban runoff: American Water Resources Association, Water Resources Bulletin, v. 22, no. 3, p. 447-455.

Helsel, D.R., and Hirsch, R.M., 1992, Statistical methods in water resources: New York, Elsevier Science Publishers, $522 \mathrm{p}$.

Hem, J.D., 1992, Study and interpretation of the chemical characteristics of natural water: U.S. Geological Survey Water-Supply Paper 2254, 263 p.

Jones, R.C., and Clark, C.C., 1987, Impact of watershed urbanization on stream insect communities: Water Resources Bulletin, v. 23, p. 1047-1055.
Klein, R.D., 1979, Urbanization and stream quality impairment: American Water Resources Association, Water Resources Bulletin, v. 15, no. 4, p. 948-963.

Lenat, D.R., and Crawford, J.K., 1994, Effects of land use on water quality and aquatic biota of three North Carolina Piedmont streams: Hydrobiologia, v. 294, p. 185-199.

May, C.W., Horner, R., Karr, J.R., Mar, B., and Welch, E., 1997, Effects of urbanization on small streams in the Puget Sound Lowland Ecoregion: Watershed Protection Techniques, v. 2, no. 4, p. 483-494.

New Hampshire Department of Environmental Services, 2004, 2004 section 305 (b) and 303 (d) consolidated assessment and listing methodology: Concord, N.H., variously paged.

New Hampshire Estuaries Project, 2003, 2003 State of the Estuaries Report: Concord, N.H., 32 p.

Ourso, R.T., and Frenzel, S.A., 2003, Identification of linear and threshold responses in streams along a gradient of urbanization in Anchorage, Alaska: Hydrobiologia, v. 501, p. 117-131.

Pederson, E.R., and Perkins, M.A., 1986, The use of benthic invertebrate data for evaluating impacts of urban runoff: Hydrobiologia, v. 139, p. 13-22.

Rantz, S.E., 1982, Measurement and computation of streamflow: volume 1. measurement of stage and discharge: U.S. Geological Survey Water-Supply Paper 2175, p. 1-284.

Rosenberg, D.M., and Resh, V.H., 1993, Freshwater biomonitoring and benthic macroinvertbrates: New York, Chapman and Hall, Thomson Publishing, 488 p.

Rubin, F.A., and Justice, D.G., 2001. Impervious surface mapping in the Exeter River watershed: Durham, N.H., University of New Hampshire, Complex Systems Research Center, 4 p.

SAS Institute, Inc., 1998, Statview user's guide, version 5: Cary, N.C., SAS Institute, Inc.

SAS Institute, Inc, 2000, SAS/STAT user's guide, version 8: Cary, N.C., SAS Institute, Inc.

Schueler, T.R., 1994, The importance of imperviousness, in Schueler, T.R. and Holland, H.K., eds., The practice of watershed protection: Ellicott City, Md., Center for Watershed Protection, p. 7-18.

Schueler, T.R., and Galli, J., 1992, Environmental impacts of stormwater ponds, in Watershed restoration source book: Washington, D.C., Metropolitan Washington Council of Governments, $242 \mathrm{p}$. 
Shaver, E., Maxted, J., Curtis, G., and Carter, D., 1994, Watershed protection using an integrated approach, in Torno, H.C., (ed.) Stormwater National Pollutant Discharge Elimination System related monitoring needs: Proceedings of an Engineering Foundation Conference, Crested Butte, Colo., American Society of Civil Engineers, p. 435-459.

Stevens, M.S., and Anderson, J.E. 1997, Conservation plan for the Great Bay Region: Concord, N.H., The Nature Conservancy, New Hampshire Field Office, 88 p.

Short, F.T., ed., 1992, The ecology of Great Bay Estuary, New Hampshire and Maine: An estuarine profile and bibliography: National Oceanic and Atmospheric Administration Coastal Ocean Program Publication, 222 p.

U. S. Geological Survey, 1995, Digital Line Graph (DLG) hydrography data, 1:24,000-scale, accessed November 2004, at http://edc.usgs.gov/products/map/dlg.html.
U.S. Geological Survey, 2000, National land cover data (NLCD) circa 1992, completed nationwide September 2000, accessed November 2004, at http://seamless.usgs.gov/.

Wang, L., Lyons, J., Kanehl, P., and Gatti, R., 1997, Influences of watershed land use on habitat quality and biotic integrity in Wisconsin streams: Fisheries, v. 22, no. 6, p. 6-12.

Wilde, F.D., and Radtke, D.B., 1998a, Collection of water samples: U.S. Geological Survey Techniques of WaterResources Investigations, Handbooks for Water-Resources Investigations, National field manual for the collection of water-quality data, book 9, chap. A4, variously paginated.

Wilde, F.D., and Radtke, D.B., 1998b, Field measurements: U.S. Geological Survey Techniques of Water-Resources Investigations, Handbooks for Water-Resources Investigations, National field manual for the collection of water-quality data, book 9, chap. A6, variously paginated. 
Prepared by the New Hampshire-Vermont Water Science Center Publications Unit

For more information concerning the research in this report, contact:

Brian Mrazik, Director,

U.S. Geological Survey

NH-VT Water Science Center

361 Commerce Way

Pembroke, NH 03275

dc_nh@usgs.gov

or visit our Web site at:

http://nh.water.usgs.gov 